
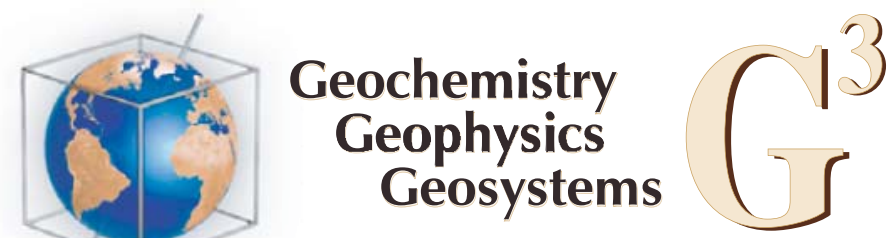

Published by AGU and the Geochemical Society

ISSN: $1525-2027$

\title{
Lithosphere versus asthenosphere mantle sources at the Big Pine Volcanic Field, California
}

\author{
Esteban Gazel \\ Department of Geosciences, Virginia Polytechnic Institute and State University, Blacksburg, Virginia \\ 24061, USA (egazel@vt.edu) \\ Lamont-Doherty Earth Observatory, Earth Institute at Columbia University, Palisades, Nerw York \\ 10964, USA

\section{Terry Plank} \\ Lamont-Doherty Earth Observatory, Earth Institute at Columbia University, Palisades, New York \\ 10964, USA
}

\section{Donald W. Forsyth}

Department of Geological Sciences, Brown University, Providence, Rhode Island 02912, USA

\author{
Claire Bendersky \\ Lamont-Doherty Earth Observatory, Earth Institute at Columbia University, Palisades, Nerw York \\ 10964, USA
}

\author{
Cin-Ty A. Lee \\ Department of Earth Science, Rice University, Houston, Texas 77005, USA
}

\author{
Erik H. Hauri \\ Department of Terrestrial Magnetism, Carnegie Institution of Washington, Washington, DC 20878, \\ USA
}

[1] Here we report the first measurements of the $\mathrm{H}_{2} \mathrm{O}$ content of magmas and mantle xenoliths from the Big Pine Volcanic Field (BPVF), California, in order to constrain the melting process in the mantle, and the role of asthenospheric and lithospheric sources in this westernmost region of the Basin and Range Province, western USA. Melt inclusions trapped in primitive olivines $\left(\mathrm{Fo}_{82-90}\right)$ record surprisingly high $\mathrm{H}_{2} \mathrm{O}$ contents (1.5 to 3.0 wt.\%), while lithospheric mantle xenoliths record low $\mathrm{H}_{2} \mathrm{O}$ concentrations (whole rock $<75 \mathrm{ppm}$ ). Estimates of the oxidation state of BPVF magmas, based on V partitioning in olivine, are also high (FMQ +1.0 to +1.5). Pressures and temperatures of equilibration of the BPVF melts indicate a shift over time, from higher melting temperatures $\left(\sim 1320^{\circ} \mathrm{C}\right)$ and pressures $(\sim 2 \mathrm{GPa})$ for magmas that are $>500 \mathrm{ka}$, to cooler $\left(\sim 1220^{\circ} \mathrm{C}\right)$ and shallower melting $(\sim 1 \mathrm{GPa})$ conditions in younger magmas. The estimated depth of melting correlates strongly with some trace element ratios in the magmas (e.g., $\mathrm{Ce} / \mathrm{Pb}, \mathrm{Ba} / \mathrm{La}$ ), with deeper melts having values closer to upper mantle asthenosphere values, and shallower melts having values more typical of subduction zone magmas. This geochemical stratification is consistent with seismic observations of a shallow lithosphere-asthenosphere boundary ( $\sim 55 \mathrm{~km}$ depth). Combined trace element and cryoscopic melting models yield self-consistent estimates for the degree of melting $(\sim 5 \%)$ and source $\mathrm{H}_{2} \mathrm{O}$ concentration $(\sim 1000 \mathrm{ppm})$. We suggest two possible geodynamic models to explain small-scale convection necessary for magma generation. The first is related to the Isabella seismic anomaly, either a remnant of the Farallon Plate or foundered lithosphere. The second scenario is related to slow extension of the lithosphere. 
Components: 15,500 words, 12 figures.

Keywords: Basin and Range; lithosphere-asthenosphere boundary; melt inclusions; shear wave tomography.

Index Terms: 1009 Geochemistry: Geochemical modeling (3610, 8410); 1038 Geochemistry: Mantle processes (3621); 1065 Geochemistry: Major and trace element geochemistry.

Received 19 January 2012; Revised 7 May 2012; Accepted 14 May 2012; Published 27 June 2012.

Gazel, E., T. Plank, D. W. Forsyth, C. Bendersky, C.-T. A. Lee, and E. H. Hauri (2012), Lithosphere versus asthenosphere mantle sources at the Big Pine Volcanic Field, California, Geochem. Geophys. Geosyst., 13, Q0AK06, doi:10.1029/2012GC004060.

Theme: The Lithosphere-Asthenosphere Boundary

\section{Introduction}

[2] The lithosphere is the strong lid at the surface of planet Earth [Barrell, 1914; Jordan, 1978]. This lid defines the different tectonic plates and consists of the crust and rigid uppermost mantle that moves on top of the viscous asthenospheric mantle. By definition these two mechanical layers are separated by some kind of rheological or thermal lithosphereasthenosphere boundary (LAB) [e.g., Artemieva, 2006]. In most cases this boundary has been correlated with a seismic low velocity zone below [e.g., Rychert and Shearer, 2009; Rychert et al., 2010] that can be produced by high temperature [e.g., Ritzwoller et al., 2004], partial melt [Hammond and Humphreys, 2000; Jackson et al., 2004], and the presence of volatiles that reduce the velocity through anelastic effects [Karato, 2003; Hirschmann, 2010].

[3] To further understand the role of these different possibilities in the creation, evolution and seismic properties of the lithosphere-asthenosphere boundary (LAB), it is necessary to integrate seismological observations with petrological and geochemical interpretations. The Basin and Range Province in the western USA is a region where the lithosphere is actively evolving and where both lithospheric and asthenospheric mantle sources have been invoked to explain the geochemistry of widespread mafic volcanism in the last $10 \mathrm{Ma}$ [e.g., Perry et al., 1987; Ormerod et al., 1988; Farmer et al., 1989; Fitton et al., 1991; Leeman and Harry, 1993; DePaolo and Daley, 2000]. This region has also recently been sampled by EarthScope's Transportable Array, a leapfrogging array of broadband seismometers spaced approximately $70 \mathrm{~km}$ apart which allows for uniform and thorough imaging of upper mantle structure aiding in the investigation of the evolution of the LAB below continents and by temporary arrays focused on the Sierra Nevada.
[4] The tectonic processes and melting mechanisms that generated this mafic volcanism are still controversial. For example, mantle upwelling in response to plate extension is argued as one of the main processes for melt generation in the Basin and Range, similar to mid-ocean ridges [McKenzie and Bickle, 1988; Leeman and Harry, 1993; DePaolo and Daley, 2000; Wang et al., 2002]. This model is widely accepted because parts of the Basin and Range have been undergoing local episodes of extension for more than $30 \mathrm{Ma}$ [e.g., Wernicke et al., 1987; McQuarrie and Oskin, 2010], and in several regions the timing of crustal extension coincides with changes in basalt composition that is consistent with a shift in the magma source from lithosphere to asthenosphere [DePaolo and Daley, 2000].

[5] However, other mechanisms have been suggested to explain the recent magmatism in the Basin and Range. Shear wave splitting data and topography have been interpreted as evidence for active mantle upwelling on a large scale [Savage and Sheehan, 2000; Lowry et al., 2000]. The passage of the Farallon slab may also drive asthenosphere upwelling [Ormerod et al., 1988]. A mantle melting profile across the Basin and Range, based on inverting basalt compositions [Wang et al., 2002], suggests mantle temperature variations as the primary control on the depth of melting, implying a dynamic convective process. Strong heterogeneities in the lithosphere [Farmer et al., 1989; Lee et al., 2001; Lee, 2005] may have accumulated throughout the Phanerozoic. Dueker et al. [2001] argued that volcanism in the Basin and Range occurs above Proterozoic sutures, which may contain easily fusible components. Dixon et al. [2004] and Humphreys et al. [2003] pointed to Farallon subduction as a major source of water to the lithosphere of the western USA, and as the ultimate control on volcanism, seismic structure and rheological 
behavior. Many recent studies point to lithospheric foundering or drips [West et al., 2009; Levander et al., 2011; Crow et al., 2011], and that these "drips" have led to upwelling and thus magmatism, notably in southern California [Jones et al., 1994; Ducea and Saleeby, 1996; Zandt et al., 2004; Yang and Forsyth, 2006; Frassetto et al., 2011]. Also, the absolute motion of the North American Plate could produce small-scale convection that focuses melting and volcanism into SW-NE linear trends [Dueker et al., 2001]. Finally, numerical models suggest that mantle upwelling in high-shear regions like the western United States could be triggered by viscosity variations due to compositional heterogeneity, particularly mineral hydration in the mantle [Conrad et al., 2011].

[6] A petrological determination of the temperature and pressure conditions in the melting region is thus useful to understand the drivers of melting beneath the Basin and Range. These conditions are recorded in the major element composition (e.g., $\mathrm{SiO}_{2}, \mathrm{FeO}$ and $\mathrm{MgO}$ ) of primitive mantle-derived magmas, but knowledge of $\mathrm{Fe}^{3+}$ and water contents of those magmas is necessary to provide accurate results. Melt inclusions, small (micro-meter sized) droplets of melt trapped during crystal growth, can be measured directly to obtain the $\mathrm{Fe}^{3+}$ and volatile (including water) contents of magma prior to ascent and degassing [e.g., Johnson et al., 2009; Kelley and Cottrell, 2009].

[7] The Big Pine Volcanic Field (BPVF) located in Owens Valley, California, east of the Sierra Nevada (Figure 1) is an ideal study site for determining melting conditions in the western Basin and Range for several reasons. (1) The BPVF consists of over 20 young volcanic vents that range from $\sim 1.3 \mathrm{Ma}$ to $32 \mathrm{ka}$ and produced basaltic lavas and tephras with abundant mantle xenoliths [Ormerod et al., 1991; Beard and Glazner, 1995; Blondes et al., 2007; Kirby et al., 2008]. This is ideal for obtaining undegassed melt inclusion because mantle xenolith transport and pyroclastic deposits require rapid magma ascent, which limits $\mathrm{H}_{2} \mathrm{O}$-loss from the magma and melt inclusion. (2) The region also has been affected by Farallon subduction (18-20 Ma), Basin and Range extension beginning at $\sim 12 \mathrm{Ma}$, and transtension ongoing since the Pliocene [Stockli et al., 2003; Phillips and Majkowski, 2011; Jones et al., 2004], providing information about the relationship of magmatism to tectonism. (3) Blondes et al. [2008] concluded that crustal contamination is not a major process for the BPVF, based on radiogenic isotopes, trace element systematics, uniform $\mathrm{MgO}$ contents ( $>6 \mathrm{wt} \%$ ) and the abundance of mantle xenoliths. (4) Several vents in the BPVF display monotonic and large temporal variations in magma chemical composition, consistent with binary mixing of distinct mantle melts over the course of single eruptive episodes [Blondes et al., 2008].

[8] Many lines of evidence point to lithospheric thinning beneath the BPVF. Shallow mantle here has low $\mathrm{P}$ and $\mathrm{S}$ velocities [e.g., Wernicke et al., 1996; Jones and Phinney, 1998; Savage et al., 2003; Boyd et al., 2004; Yang and Forsyth, 2006]. If this anomaly reflects hot or partially molten asthenosphere, little room is left for a cold and rigid mantle lithosphere below the Moho. Ormerod et al. [1991] used trace element inverse modeling to exclude garnet in the source, limiting melting depth to $<90 \mathrm{~km}$. Spinel-bearing peridotite xenoliths hosted in the BPVF lavas record Ca-in orthopyroxene temperatures of $1000-1100^{\circ} \mathrm{C}$, and equilibration depths as shallow as $35 \mathrm{~km}$, indicating a lithospheric origin [Lee et al., 2000]. Some of the lavas contain clinopyroxenes that last equilibrated with melt as deep as $\sim 55 \mathrm{~km}$ [Mordick and Glazner, 2006] suggesting rapid melt extraction and cooling above this region. This suite of observations point to the Big Pine volcanics as recorders of a thinned lithosphere-asthenosphere (LAB) boundary.

[9] Here, we present quantitative petrologic information on primitive samples from the BPVF, guided by our new data on melt inclusions hosted in olivine (Fo 82-90) and water contents in mantle xenoliths. These new results are combined with surface wave inversions that constrain the mantle shear velocity structure. We discuss possible melting mechanisms within the context of evolving lithosphere and asthenosphere mantle in the recent volcanism in the Basin \& Range by exploring these fundamental questions at BPVF: (1) Does the melt composition change at BPVF with depth, reflecting distinct chemical boundaries in the mantle? (2) What is the relationship between petrologically derived $\mathrm{T}$ and $\mathrm{P}$ estimates and the rheological changes at the LAB? (3) Is the LAB a boundary where mantle rheology changes, and/or an area where melt segregates and accumulates?

\section{Samples, Data and Analytical Methods}

[10] Scoria samples were collected from cinder cones from the BPVF in 2008 (locations shown in 


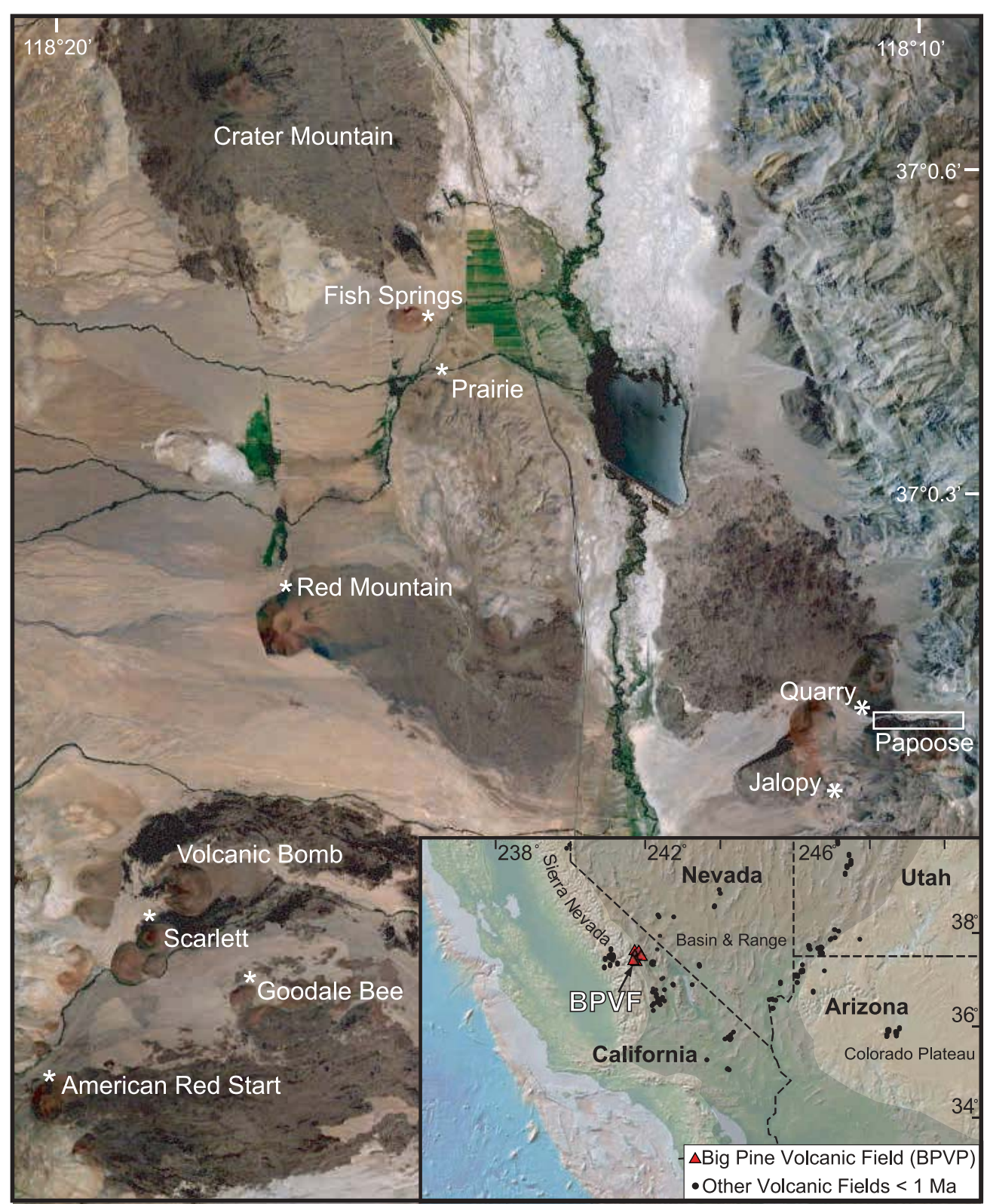

Figure 1. Map of the BPVF with sample locations (asterisks). The inset map shows the location of the BPVF and other $<1$ Ma volcanic fields in the Basin and Range. Satellite photograph from Google Earth, Western USA from GeoMapApp, and location and ages of the volcanic fields from NavDat. Google Earth imagery (c) Google Inc. Used with permission.

Figure 1 and Table $\mathrm{S} 1$ in the auxiliary material). ${ }^{1}$ Because of the focus on volatile concentrations, fine lapilli and ash deposits were targeted, as melt inclusions from these samples ascended and cooled rapidly (minutes to hours), thus limiting the time available for diffusive loss of $\mathrm{H}_{2} \mathrm{O}$ through olivine. All melt inclusions were selected from pyroclasts

\footnotetext{
${ }^{1}$ Auxiliary materials are available in the HTML. doi:10.1029/ 2012GC004060.
}

$<2 \mathrm{~cm}$ in diameter, which based on our recent finding [Lloyd et al., 2010], experience minimal $\mathrm{H}_{2} \mathrm{O}$ loss during ascent and cooling.

[11] After crushing and sieving, olivines were handpicked under a binocular microscope to select those with naturally glassy, fully enclosed, $>30$ micron melt inclusions. Inclusions were exposed, individually polished, and mounted in indium for volatile analysis by ion probe at the Carnegie Institution of 
A)
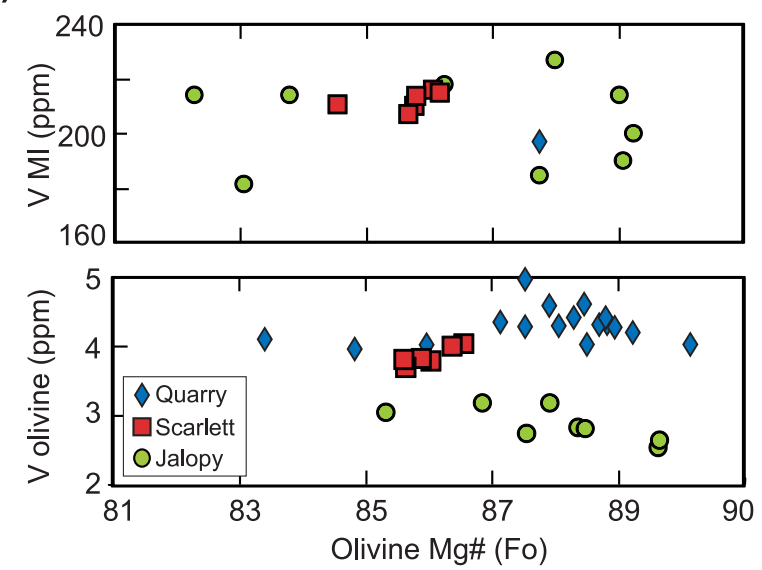

B)

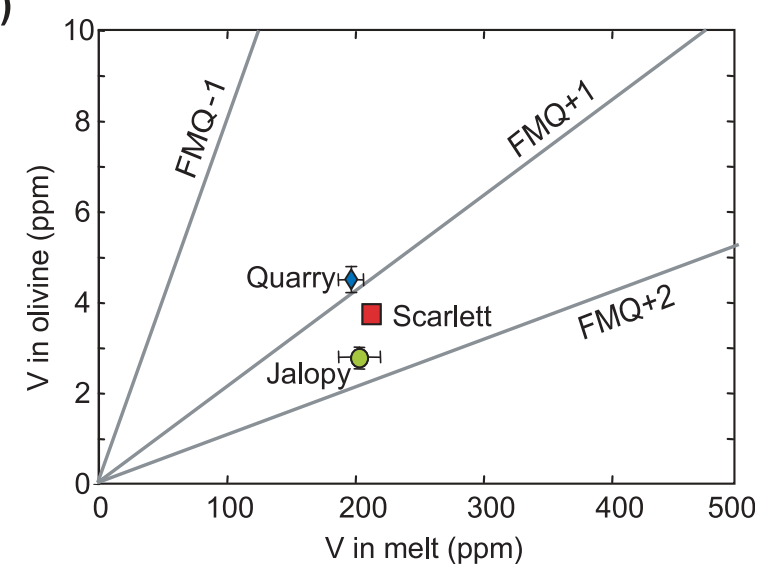

Figure 2. Results from the $\mathrm{D}_{(\mathrm{V}) \mathrm{l} / \mathrm{liq}}$ oxybarometer for the three cinder cones with least evolved compositions. (a) The concentrations of $\mathrm{V}$ in melt inclusions and olivines (determined by laser ablation ICP-MS, auxiliary material) and (b) the oxidation state estimates derived from the Canil [2002] calibration.

Washington, major elements by electron probe at the American Museum of Natural History (AMNH), and trace elements by laser ablation ICP-MS at LDEO, in that order (see auxiliary material for data and analytical conditions). Host olivines, augmented by others from the same sample to expand the population, were also analyzed for major and trace elements by electron probe and laser ablation ICP-MS, respectively. Whole rock tephra (and some lava samples from the same cones) were crushed, picked, cleaned and powdered, then analyzed for major elements by XRF at Washington State University, and trace elements by ICP-MS at Lamont (auxiliary material).

[12] Pyroxenes from lithospheric mantle xenoliths from the well characterized Oak Creek location (reported in Lee [2005]) were also analyzed for major and trace elements and volatile contents (data in the auxiliary material).

\section{Data Treatment}

\subsection{Oxidation State}

[13] Constraining magma oxidation state is crucial not only in evaluating melt inclusion and host olivine equilibrium and correcting for post-entrapment crystallization within the inclusion, but also in calculating primary compositions in equilibrium with the melting mantle. Critical to all of these issues is the proportion of $\mathrm{Fe}$ that exists as $\mathrm{Fe}^{3+} \mathrm{vs} \mathrm{Fe}^{2+}$, as only $\mathrm{Fe}^{2+}$ strongly affects olivine-melt equilibrium. Direct measurement of the $\mathrm{Fe}^{3+} / \mathrm{Fe}_{\mathrm{T}}$ (total) ratio in melt inclusions is now possible through micro-Xanes [Kelley and Cottrell, 2009], although this technique is still not widely available for large throughput measurements. Thus, we apply here another oxybarometer, the partition coefficient of $\mathrm{V}$ between melt and olivine [e.g., Canil, 2002; Mallmann and O'Neill, 2009]. Vanadium may exist as multiple species in magmas, $\mathrm{V}^{2+}, \mathrm{V}^{3+}, \mathrm{V}^{4+}$ and $\mathrm{V}^{5+}$, the proportions of which depend on $\mathrm{fO}_{2}$. In olivine, compatibility increases from $\mathrm{V}^{5+}$ to $\mathrm{V}^{4+}$ to $\mathrm{V}^{3+}$, and from this, the bulk $\mathrm{V}$ partitioned between co-existing olivine and melt has been calibrated as a function of $\mathrm{fO}_{2}$. We use the expression in Canil [2002], which agrees well with the parameterizations in Mallmann and O'Neill [2009] for a wide range of $\mathrm{fO}_{2}$ and compositions.

[14] Figure 2 shows the results of the $\mathrm{D}_{(\mathrm{V}) \mathrm{o} / \mathrm{liq}}$ oxybarometer. For three cinder cones with the least evolved compositions $(\mathrm{MgO}>6 \%$ wt: Jalopy, Scarlett and Quarry cones), olivines and melt inclusions were analyzed for $\mathrm{V}$ by laser ablation ICP-MS (Table S7 in in the auxiliary material). In Jalopy and Quarry cones, V in olivine increases slightly as forsterite content decreases, but concentrations are uniformly lower in Jalopy than Quarry despite similar V contents in the melt inclusions (Figure 2a). This leads to a lower $\mathrm{D}_{(\mathrm{V})}$, and thus higher $\mathrm{fO}_{2}$ $(F M Q+1.6$, Figure $2 b)$, for Jalopy cone than for Quarry cone (FMQ + 0.9, Figure 2b). In Scarlett cone olivines, $\mathrm{D}_{(\mathrm{V})}$ and $\mathrm{fO}_{2}$ are intermediate between the other two (Figure 2b). The oxidation states estimated from $\mathrm{V}$ predict significant $\mathrm{Fe}^{3+}$ in these magmas, from $23-30 \% \mathrm{Fe}^{3+} / \mathrm{Fe}_{\mathrm{T}}$ (using the expression in Kress and Carmichael [1991] to relate $\mathrm{fO}_{2}$ to $\mathrm{Fe}^{3+}$; see Table $\mathrm{S} 1$ for values ascribed to each cone).

[15] The oxidized nature of Jalopy magmas is noteworthy, as it approaches the most oxidized arc melt inclusions $\left(25-30 \% \mathrm{Fe}^{3+} / \mathrm{Fe}_{\mathrm{T}}\right.$ [Kelley and 


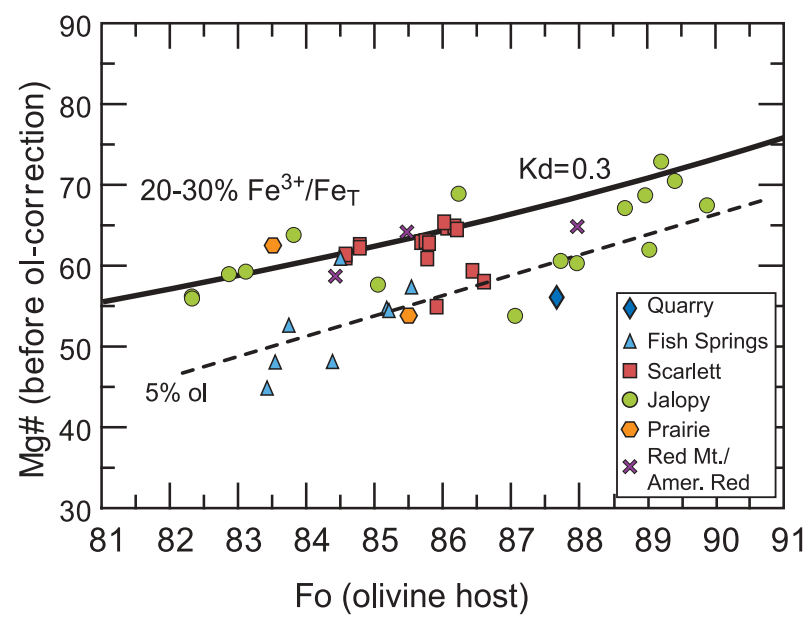

Figure 3. Evaluation of melt inclusion-host olivine equilibrium. Note that melts in equilibrium with the host olivine lie on equilibrium line using a constant $\mathrm{K}_{\mathrm{D}}$ ol-lig $\left(\mathrm{Fe}^{2+} / \mathrm{Mg}\right)=0.3$ and the $\mathrm{Fe}^{3+} / \mathrm{Fe}_{\mathrm{T}}=20-30 \%$ for each melt inclusion as determined from the $\mathrm{V}$ proxy. The rest of the melt inclusions require post entrapment crystallization correction on average of $<6 \%$.

Cottrell, 2009]). Independent support for the high oxidation state of Jalopy magmas comes from the very high sulfur contents of the least degassed melt inclusions $(\sim 5000 \mathrm{ppm} \mathrm{S}$; Table S1), consistent with FMQ $>+1$ [Jugo et al., 2010]. In their most recent work, Kelley and Cottrell [2012] reported four micro-Xanes analyses of Jalopy melt inclusions (different inclusions from the same sample reported here), and obtain $\mathrm{Fe}^{3+} / \mathrm{Fe}_{\mathrm{T}}$ of $24-25 \%$. These data, along with a broader survey of coupled $\mathrm{V}-\mathrm{Fe}^{3+}$ measurements in Kelley and Cottrell [2012], support the use of the $\mathrm{V}$ oxybarometer, and the oxidized nature of Big Pine magmas.

\subsection{Equilibrium and Post-entrapment Crystallization}

[16] It is important to evaluate the equilibrium of a melt inclusion with its olivine host because it is possible that olivine may precipitate at/or near the host walls or elements may exchange with the olivine and melt during cooling [e.g., Danyushevsky et al., 2002]. For this, we first evaluate the Fe-Mg equilibrium with the host olivine by comparing the $\mathrm{Mg \#}$ (before any correction) of the melt inclusion versus the Fo content of the olivine host. Melts in equilibrium with the host olivine should lie on the equilibrium line in Figure 3 (using a constant $\mathrm{K}_{\mathrm{D}}$ ol-lig $\left(\mathrm{Fe}^{2+} / \mathrm{Mg}\right)=0.3$ and the $\mathrm{Fe}^{3+} / \mathrm{Fe}_{\mathrm{T}}=20-30 \%$ for each melt inclusion determined from the $\mathrm{V}$ proxy (Table S1).
[17] Notably, most melt inclusions from Jalopy and Scarlett cones erupted in equilibrium with their host olivines, even for very primitive compositions $\left(\mathrm{Fo}_{89-90}\right)$. This is consistent with the fast cooling of the small fraction collected (ash and $<2 \mathrm{~cm}$ lapilli), and rapid ascent in the volcanic conduit. On the other hand, all the inclusions from Fish Springs cone reflect post entrapment crystallization, requiring a correction on average of $<6 \%$ (Figure 3 ). These melt inclusions were corrected for postentrapment crystallization by adding olivine until equilibrium with the host olivine was reached. The corrected values are reported in the auxiliary material (Table S1).

\section{Results}

\subsection{Major and Trace Element Composition and Fractional Crystallization}

[18] After post-entrapment crystallization correction, the olivine hosted melt-inclusion data range from basalts and trachy-basalts to basaltic trachyandesites, similar to the bulk rocks of the BPVF (Figure 4a). Almost all of the BPVF volcanics and melt inclusions belong to the alkaline series (high $\mathrm{K}_{2} \mathrm{O}>1 \mathrm{wt} \%$ and nepheline normative). The melt inclusion data are in the same range as the bulk rock chemistry from the same vent with the exception of Jalopy cone, where melt inclusions have uniformly higher alkalies and lower $\mathrm{SiO}_{2}$ and $\mathrm{MgO}$ (Figure $4 \mathrm{a}$ ). The samples with $\mathrm{MgO}$ values $>6 \%$ are consistent with modeled liquid lines of descent (LLD) controlled mostly by olivine crystallization (Figures $4 \mathrm{~b}-4 \mathrm{~d}$ ). The systematic decrease in $\mathrm{FeO}$ and $\mathrm{CaO}$, and increase in $\mathrm{Al}_{2} \mathrm{O}_{3}$ in samples with $\mathrm{MgO}<6 \%$ is consistent with clinopyroxene and magnetite fractionation (Figures $4 \mathrm{~b}$ and $4 \mathrm{c}$ ). These systematics are expected given the sample petrography, where olivine is the main crystalline phase in BPVF lavas, followed by minor $(<5 \%)$ clinopyroxene and plagioclase in some of the more fractionated samples [Blondes et al., 2008; this study]. Fish Springs cinders also contain amphibole crystals. Also, within the Jalopy melt inclusions there is a minor population with high $\mathrm{CaO}$ (Figure 4b). Similar high-CaO inclusions have been found worldwide, typically in Fo $>86$ olivines, often with anomalous major and trace elements [Schiano et al., 2000; Danyushevsky et al., 2002]. These high-Ca inclusions, along with those that bear clear evidence of clinopyroxene fractionation, were excluded from the petrologic modeling below because their compositions are too evolved from primitive mantle 
A)

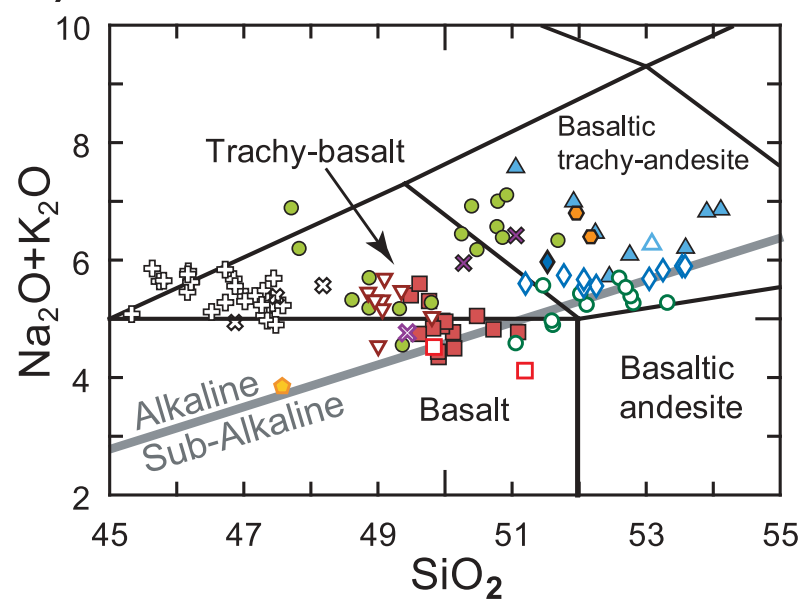

B)

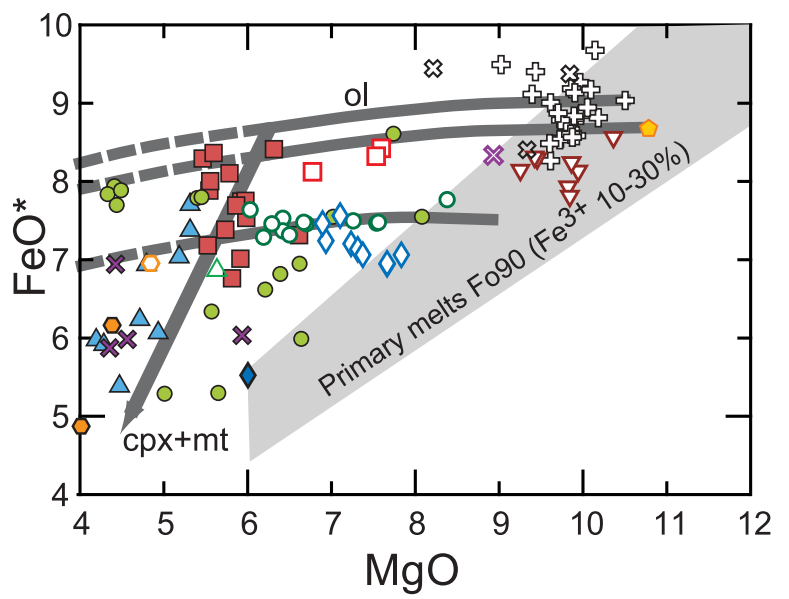

C)

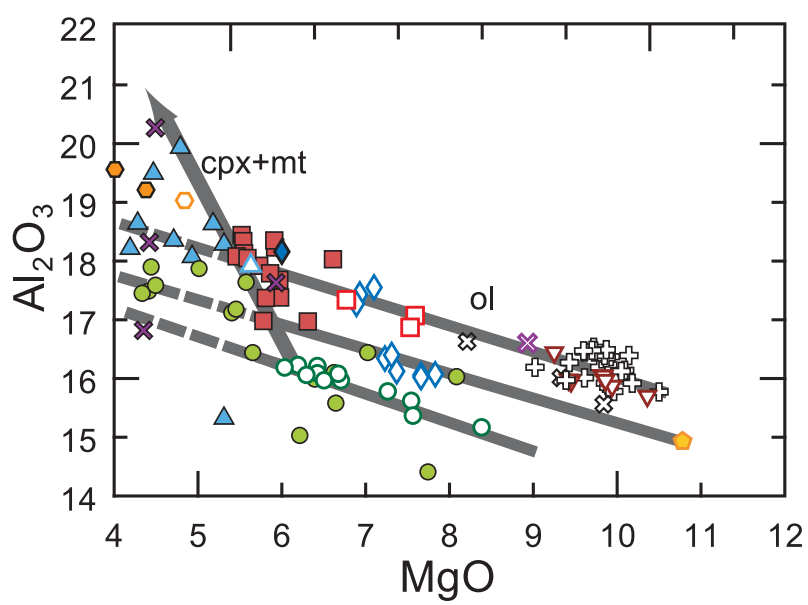

D)

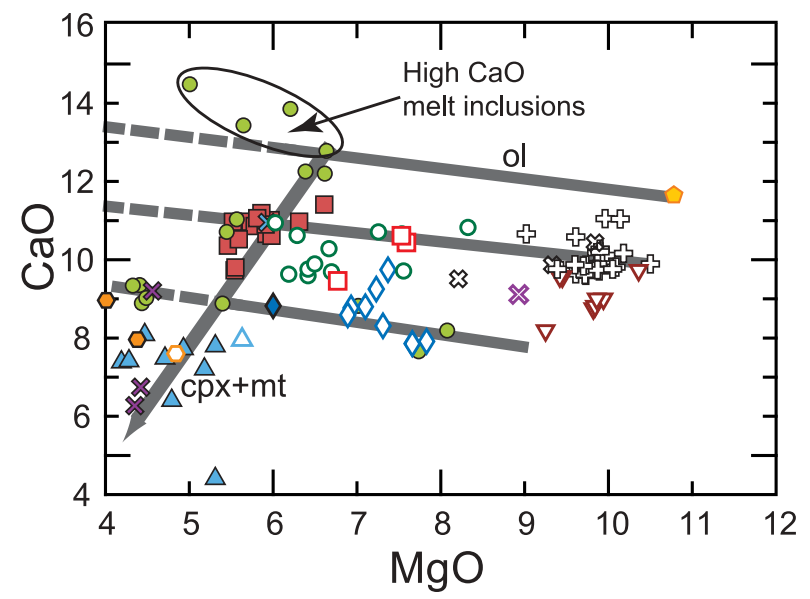

\begin{tabular}{|c|c|c|}
\hline Melt Inclusions & Tephra/Lava & \\
\hline$\diamond$ Quarry & $\nabla$ Goodale/Volcanic Bomb & $\square$ Prairie \\
\hline$\triangle$ Fish Springs & $(31.8 \pm 12.1 / 61.6 \pm 23.4 \mathrm{ka})$ & X American Red Start \\
\hline Jalopy & $\diamond$ Quarry $(90.5 \pm 17.6 \mathrm{ka})$ & \\
\hline$\square$ Scarlett & $\triangle$ Fish Springs $(273 \pm 23 \mathrm{ka})$ & Sawmill \\
\hline 0 Prairie & Jalopy (469.4 $\pm 9.2 \mathrm{ka})$ & 凸 Papoose $(760.8 \pm 22.8 \mathrm{ka})$ \\
\hline « Red Mt./Amer. Red Start & $\square$ Scarlett & $\rightsquigarrow$ Oak Creek A\&C $(1273 \pm 22.8 \mathrm{ka})$ \\
\hline
\end{tabular}

Figure 4. Major element composition (after post-entrapment crystallization correction) of the BPVF melt inclusions compared with bulk rock data from Blondes et al. [2008] and this study (Table S1). The samples with $\mathrm{MgO}$ values $>6 \%$ are consistent with modeled liquid lines of descent (LLD) controlled by olivine crystallization, while more evolved samples show evidence for clinopyroxene and magnetite fractionation ( $\mathrm{cpx}+\mathrm{mt}$ vectors in Figures $4 \mathrm{~b}-4 \mathrm{~d})$. The liquid lines of descent were modeled using Petrolog Software [Danyushevsky and Plechov, 2011], with the parameters of Beattie [1993]. In Figure 4b notice that there are two main populations of samples; the vents older than $0.7 \mathrm{Ma}$ are on olivine control trends with higher $\mathrm{FeO}$ values at a given $\mathrm{MgO}$ content than the samples younger than $0.5 \mathrm{Ma}$. The gray area indicates possible primary melt compositions in equilibrium with a mantle source with $\mathrm{Fo}_{90}$ assuming $\mathrm{Fe}^{3+} / \mathrm{Fe}_{\mathrm{T}}$ of $10-30 \%$. Considering the highly oxidized nature of the BPVF $\left(\mathrm{Fe}^{3+} / \mathrm{Fe}_{\mathrm{T}}=20-30 \%\right)$ some of the primitive samples $(\mathrm{MgO}>7 \%)$ are nearly primary in composition. Also notice in Figure $4 \mathrm{~d}$ the minor population of high $\mathrm{CaO}$ melt inclusions within Jalopy vent data. 
melts (see Lee et al. [2009] for more details on sample selection).

[19] There are two main populations of samples at the BPVF, those from vents older than 0.5 Ma (e.g., Papoose, Oak Creek A and C) and those younger (including all the cones studied here that yielded melt inclusions). The older suites lie on olivine control trends with higher $\mathrm{FeO}$ values at a given $\mathrm{MgO}$ content than the younger samples (Figure 4b). Considering the highly oxidized nature of the BPVF $\left(\mathrm{Fe}^{3+} / \mathrm{Fe}_{\mathrm{T}}=20-30 \%\right)$ some of the more magnesian samples $(\mathrm{MgO}>7 \%)$ are nearly primary in composition (gray area in Figure 4b), making this suite of samples ideal to evaluate melting processes that produced the BPVF.

[20] The melt inclusion data from Fish Springs, Red Mountain and Prairie have the same trace element patterns as the host tephra (Figures 5a-5d and Table S4 in the auxiliary material). The Scarlet melt inclusions have the same overall patterns but they are generally more enriched than the bulk-rock data from a lava flow from the same vent (Figure 5d). This relative enrichment is consistent with fractional crystallization because the lava has $\mathrm{MgO}$ close to $8 \mathrm{wt} \%$ and the melt inclusions and host tephra have less than 7\% (Figure 4). Although we do not have data for the exact host tephra that yielded the Quarry melts inclusion (Figure 5e), the overall enrichments compared to bulk-rock data from the same deposit [Blondes et al., 2008] are also consistent with fractional crystallization (see Figure 4). The Jalopy melt inclusion data show much more diverse trace element compositions compared with both the host tephra and data from the same vent reported in the literature (Figure 5f). This is consistent with the differing major element compositions as well. All of the BPVF melt inclusions show the relative enrichments of fluid mobile elements (e.g., $\mathrm{Pb}, \mathrm{Ba}$ ) and depletions in high-field strength elements (e.g., $\mathrm{Nb}, \mathrm{Ta}$ ) typical of subduction zone magmas (Figure 5).

\subsection{Volatile Content and Degassing}

[21] Although melt inclusions are trapped inside olivine hosts, they can be closed at various stages of degassing as magma ascends to the surface. The different solubility of the volatile species allows a quantitative evaluation of melt inclusion degassing [e.g., Dixon and Stolper, 1995]. $\mathrm{CO}_{2}$ is less soluble than $\mathrm{H}_{2} \mathrm{O}$ and initial ascent and vapor exsolution leads to rapid loss of $\mathrm{CO}_{2}$ from the melt, with little change in $\mathrm{H}_{2} \mathrm{O}$. This kind of degassing path is observed for the Jalopy melt inclusions (Figure 6a), and is quantitatively consistent with closed-system degassing from $>5 \mathrm{~kb}(\sim 20 \mathrm{~km})$ to the surface (using the VolatileCalc model in Newman and Lowenstern [2002]). The $\mathrm{H}_{2} \mathrm{O}-\mathrm{S}$ data also define a very coherent degassing trend for Jalopy melt inclusions, with coupled loss of $\mathrm{H}_{2} \mathrm{O}$ and $\mathrm{S}$ (Figure 6b). Given the very high $\mathrm{CO}_{2}$ and $\mathrm{S}$ contents (Figures 6a and $6 \mathrm{~b}$ ), the good fit to the degassing path, and the high Fo contents of some of the olivine hosts $\left(\sim \mathrm{Fo}_{89}\right)$, there is a high degree of confidence in the initial water content of the Jalopy magma, at $\sim 2.2 \mathrm{wt} \% \mathrm{H}_{2} \mathrm{O}$. Such water contents are surprisingly high for continental basalts, overlapping the low end of the range for arc basalts and the upper end for back-arc basin basalts [Zimmer et al., 2010]. On the other hand, Scarlett cone inclusions appear to lie on a separate degassing path, also starting at $\sim 5 \mathrm{~kb}$ and with $\sim 3000 \mathrm{ppm} \mathrm{CO}_{2}$, but at lower water contents, $\sim 1.5 \mathrm{wt} \% \mathrm{H}_{2} \mathrm{O}$ (Figure $5 b$ ).

[22] Additional support for this kind of primary variation in volatile concentrations comes from the $\mathrm{H}_{2} \mathrm{O}-\mathrm{Cl}$ systematics (Figure $6 \mathrm{c}$ ). $\mathrm{Cl}$ has a higher solubility in vapor-saturated basaltic melts than $\mathrm{H}_{2} \mathrm{O}$, and BPVF melt inclusions form linear arrays reflecting $\mathrm{H}_{2} \mathrm{O}$ loss (through either degassing or diffusion) at nearly constant $\mathrm{Cl}$. The melt inclusions with the maximum $\mathrm{H}_{2} \mathrm{O}$ contents define a common $\mathrm{H}_{2} \mathrm{O} / \mathrm{Cl}$ ratio of 66 for the BPVF, which is the upper bound of $\mathrm{H}_{2} \mathrm{O} / \mathrm{Cl}$ observed in arc and OIB melt inclusions [Ruscitto et al., 2012; Stolper et al., 2004; Koleszar et al., 2009]. The common $\mathrm{H}_{2} \mathrm{O} / \mathrm{Cl}$ ratio provides a useful baseline with which to estimate initial water contents even for partially degassed inclusions. By this argument, Fish Springs cone magmas would have the highest $\mathrm{H}_{2} \mathrm{O}$ contents at Big Pine, on the order of $3 \mathrm{wt} \% \mathrm{H}_{2} \mathrm{O}$. This cone also erupts among the most evolved magma and so these higher water contents may reflect some crystal fractionation. Taken together, the Big Pine melt inclusions record a range of undegassed $\mathrm{H}_{2} \mathrm{O}$ contents (from 1.5 to $3 \mathrm{wt} \%$ ) that vary systematically from cone to cone and are surprisingly high given the fact that BPVF is not in a subduction setting today.

[23] In order to characterize the water contents of the lithospheric mantle below BPVF we measured water concentrations in pyroxenes from well characterized mantle xenoliths hosted in the 1.3 Ma Oak Creek flow [Lee et al., 2000; Lee, 2005]. The average cpx and opx $\mathrm{H}_{2} \mathrm{O}$ contents are below $250 \mathrm{ppm}$ and $150 \mathrm{ppm}$, respectively, defining an opx/cpx ratio of 0.4 (similar to the value of 0.5 measured experimentally by Aubaud et al. [2004] and recalibrated by Aubaud et al. [2007]; but lower than 

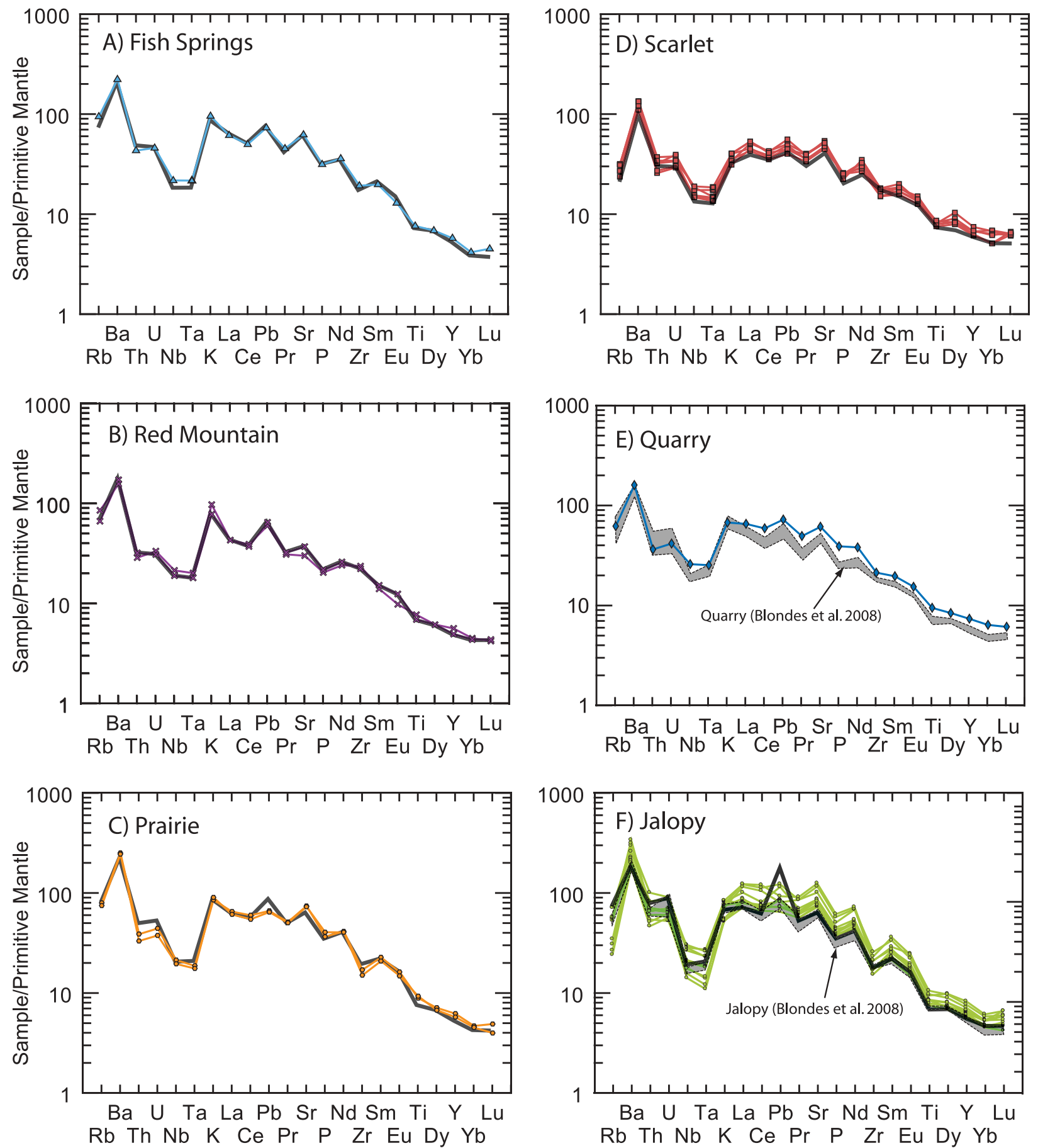

Figure 5. Primitive mantle [McDonough and Sun, 1995] normalized trace element concentrations in BPVF melt inclusions reported here. The dark gray line represents the bulk composition of the host tephra and the gray area shows the range of data from the same vent from Blondes et al. [2008].

the $0.5-0.9$ range measured experimentally by Tenner et al. [2009]). Plotted individually there is a strong negative correlation between $\mathrm{Mg} \#$ and water contents in the cpx, consistent with a melt removal processes that depletes the solid in water (an incompatible element) as $\mathrm{Mg} \#$ increases (Figure 7a).
Reconstructed bulk peridotite $\mathrm{H}_{2} \mathrm{O}$ concentrations in mantle xenoliths from the available four locations in the Western USA (Dish Hill, Grand Canyon, San Carlos from Li et al. [2008] and BPVF from this study) are plotted in Figure 7b. Only the Grand Canyon samples have water contents as high as 
A)
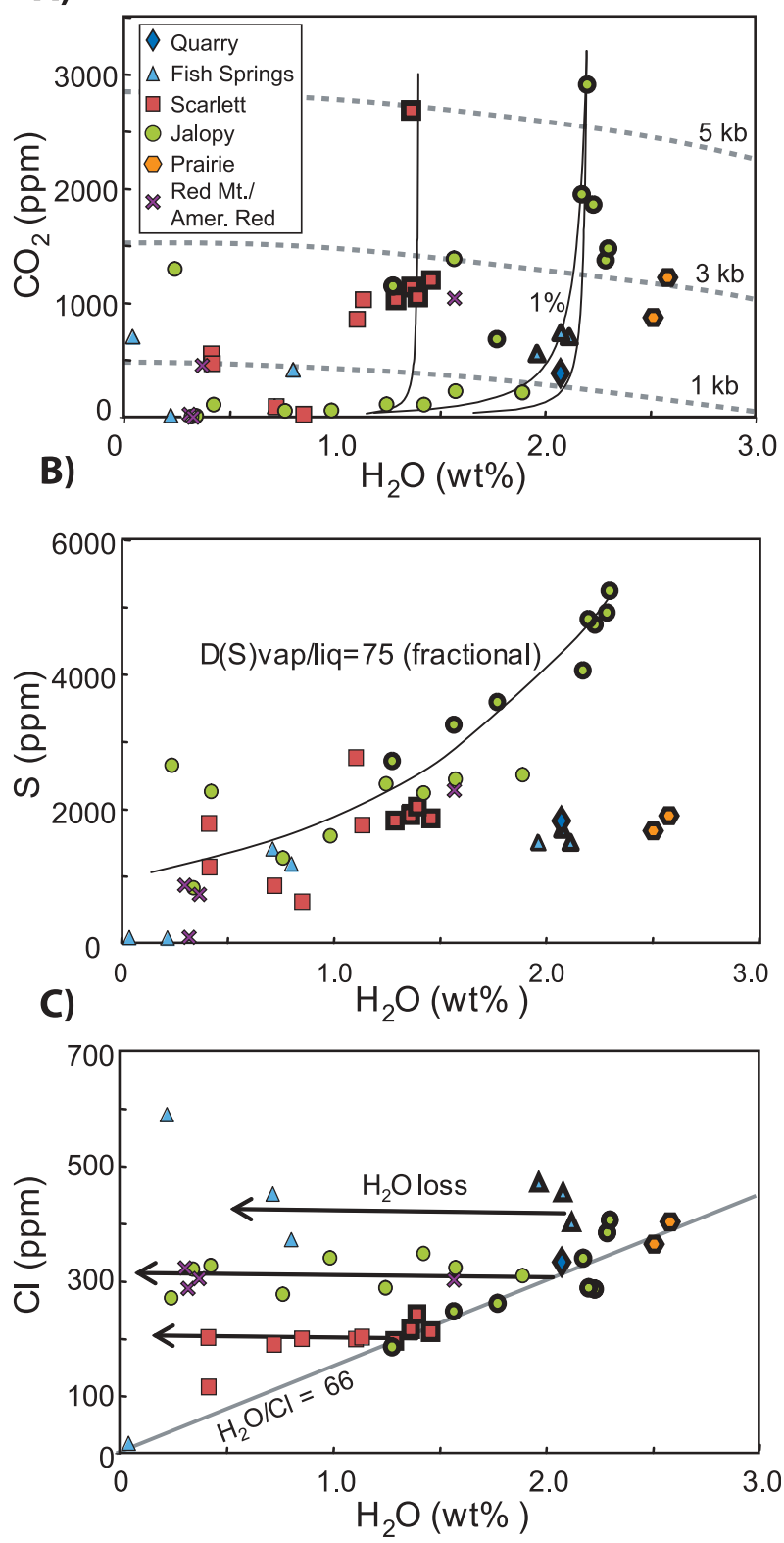

Figure 6. Volatile contents and degassing path for BPVF melt inclusions. ( $a$ and $b$ ) The degassing path for the Jalopy melt inclusions consistent with closed-system degassing from $>5 \mathrm{~kb}(\sim 20 \mathrm{~km})$. The very high $\mathrm{CO}_{2}$ and $\mathrm{S}$ contents together with the good fit to the degassing path, and the high Fo contents of some of the olivine hosts $\left(\sim \mathrm{Fo}_{89}\right)$ suggest that initial water content of the Jalopy magma is $\sim 2.2 \mathrm{wt} \% \mathrm{H}_{2} \mathrm{O}$. (c) The melt inclusions with the maximum $\mathrm{H}_{2} \mathrm{O}$ contents at each vent define a common $\mathrm{H}_{2} \mathrm{O} / \mathrm{Cl}$ ratio of 66 for the BPVF and provide a useful baseline to estimate initial water contents for even partially degassed inclusions. Bold symbols are candidates for undegassed $\mathrm{H}_{2} \mathrm{O}$.
A)

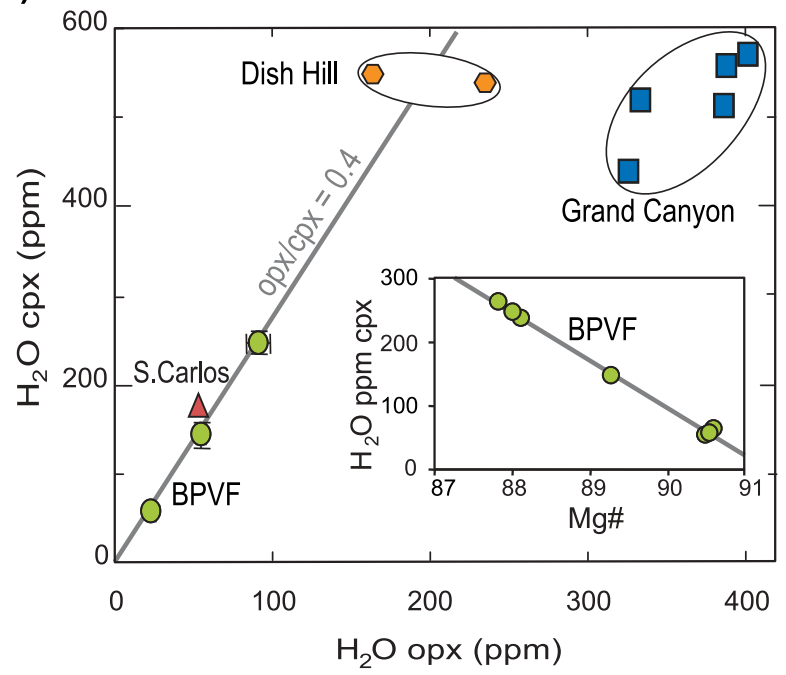

B)

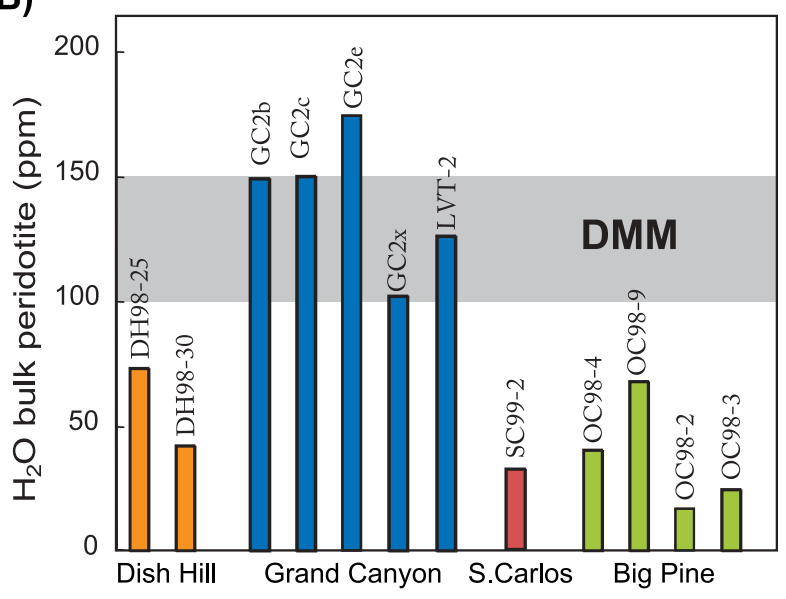

Figure 7. Water concentration in (a) mantle pyroxenes and (b) bulk peridotites from Big Pine (this work) and available data from the Western USA [Li et al., 2008]. (a) Comparison of $\mathrm{H}_{2} \mathrm{O}$ concentrations in cpx versus opx, where Big Pine, Dish Hill and San Carlos fall along opx/cpx $\mathrm{H}_{2} \mathrm{O}=0.4$ line, and Grand Canyon pyroxenes plot at higher opx/cpx. Big Pine points are averages $\pm 1 \sigma$ of several measurements within one pyroxene from three different samples. The inserted figure on the bottom right corner illustrates the strong co-variation in $\mathrm{H}_{2} \mathrm{O}$ versus $\mathrm{Mg} \#$ for individual cpx data points from Big Pine. (b) Bulk peridotite $\mathrm{H}_{2} \mathrm{O}$ concentrations in mantle xenoliths from four locations in the Western USA, calculated from modes and mineral concentrations (from $\mathrm{Li}$ et al. [2008]; and for Big Pine: modes of 53\% ol, $28 \% \mathrm{cpx}$, $15 \% \mathrm{cpx}$ and $2 \%$ spinel and $\mathrm{H}_{2} \mathrm{O}$ concentrations in pyroxenes as measured and in olivine assuming ol/cpx $\mathrm{H}_{2} \mathrm{O}=0.036$ as in Li et al. [2008]). Big Pine mantle xenoliths have uniformly lower $\mathrm{H}_{2} \mathrm{O}$ concentrations than depleted MORB mantle (DMM), compiled from Saal et al. [2002], Simons et al. [2002], Salters and Stracke [2004], and Workman and Hart [2005]. 

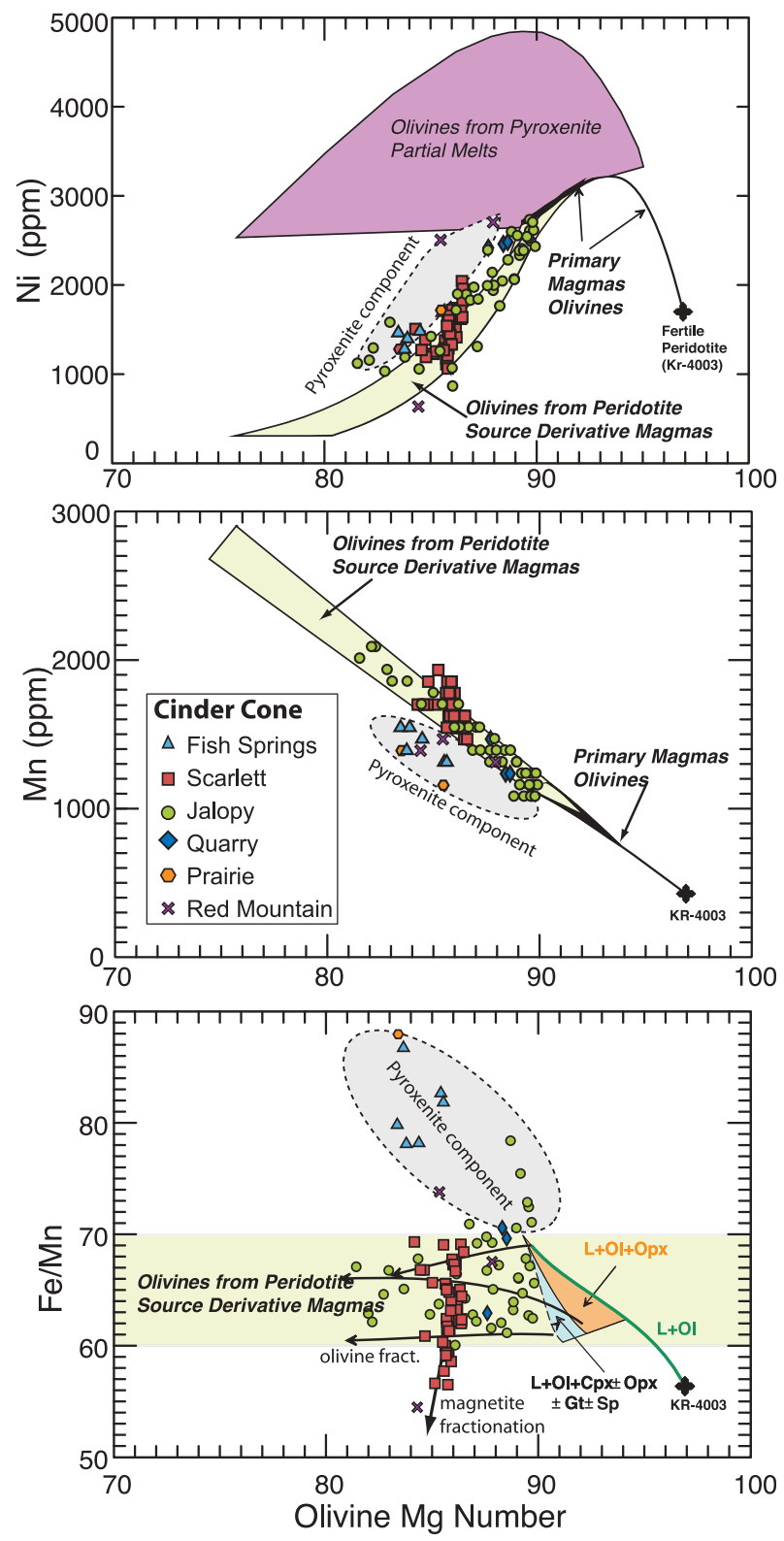

Figure 8. Discrimination of source lithology with primitive olivine composition from Herzberg [2011]. Note that most of the BPVF are consistent with a peridotite source. Samples with possible pyroxenite source or evidence of pyroxene fractionation were excluded from the thermobarometric calculations, which require melt-peridotite equilibrium.

depleted MORB mantle (DMM [Saal et al., 2002; Simons et al., 2002; Salters and Stracke, 2004; Workman and Hart, 2005]). The rest of the locations, including samples from the BPVF, have uniformly lower $\mathrm{H}_{2} \mathrm{O}$ than DMM, suggesting a "dry" lithospheric mantle below those volcanic fields. The implications of these results will be discussed below.

\subsection{Source Lithology}

[24] Determining the magma source lithology is crucial to petrological modeling based on parameterization of experimental data and observations made on mantle peridotite sources. However, exposed sections of the upper mantle often contain pyroxenites, which can dramatically affect the melt productivity and major element composition of the resulting melts [Schulze, 1989; Hirschmann and Stolper, 1996; Kogiso et al., 2004]. Isotopic studies of global basalts also suggest the presence of a recycled or metasomatic component other than peridotite in the convecting mantle [Hofmann and White, 1982; Hauri, 1996; Chauvel et al., 2008; Jackson and Dasgupta, 2008].

[25] In recent years, the development of new petrological methods based on major element geochemistry of melts and trace element compositions of olivine [e.g., Sobolev et al., 2005; Dasgupta et al., 2007; Herzberg and Asimow, 2008] have provided new information on the composition of mantle source lithology. Sobolev et al. [2005, 2007] suggested that an olivine-free pyroxenite (eclogite) source can be identified from the composition of melts that crystallized olivines having higher $\mathrm{Ni}$, lower $\mathrm{Ca}$, and high $\mathrm{Fe} / \mathrm{Mn}$ relative to peridotite-derived melts.

[26] Herzberg [2011] produced a new complete parameterization to discriminate source lithology based on olivine compositions built on the Sobolev et al. [2005, 2007] analytical work. According to these parameterizations, most of the BPVF olivines analyzed in this study have $\mathrm{Ni}, \mathrm{Mn}$ contents and $\mathrm{Fe} / \mathrm{Mn}$ consistent with magmas produced from a peridotite source (Figure 8). The relatively elevated $\mathrm{Ni}, \mathrm{Fe} / \mathrm{Mn}$ and low $\mathrm{Mn}$ contents from olivines from the Fish Springs, Prairie, Red Mountain vents and a minor subset of Jalopy vent suggest significant fractionation or even a possible pyroxenite component. The samples suspected to have a pyroxenite source were excluded from the thermodynamical modeling below because it was calibrated on experimental work on mantle peridotite - melt equilibrium [Lee et al., 2009].

[27] $\mathrm{Zn} / \mathrm{Fe}$ has also been suggested to be a useful discriminant of peridotitic versus pyroxenitic sources [Le Roux et al., 2010]. Whole-rock Zn/Fe systematics of BPVF primitive basalts are also consistent with a peridotite source [Lee, 2012].

\subsection{Melting Conditions Beneath BPVF}

[28] Understanding the temperature and composition of the melting region and its relationship to the 
continental lithosphere are keys to interpreting the processes that triggered melting below BPVF. Previous work used isotopic and trace element compositions of lavas from the Basin and Range to identify sub-continental lithospheric versus asthenospheric sources, and major element compositions to relate to depth of melting (i.e., tholeiitic shallow and alkalic deep [Ormerod et al., 1988; DePaolo and Daley, 2000]). Although this was a good initial approach, limited quantitative information was available on melting pressures $(\mathrm{P})$ or temperatures $(\mathrm{T})$.

[29] Given the primitive major element and water concentrations, $\mathrm{Fe}^{3+} / \mathrm{Fe}_{\mathrm{T}}$ estimates, and assuming a peridotite source (based on section 4.3), we can estimate the melting $\mathrm{P}$ and $\mathrm{T}$ conditions beneath the BPVF using the thermobarometer developed by Lee et al. [2009]. The thermometer in this model is based on olivine-melt Fe-Mg exchange, while the barometer is based on $\mathrm{Si}$ activity in melts saturated with orthopyroxene+olivine. In practice, we start with major element compositions from BPVF whole rocks and melt inclusions that have passed the screening criteria discussed above (olivine-only crystallization; non-anomalous $\mathrm{CaO}$; not pyroxenite source, etc.), add equilibrium olivine to them incrementally (taking into account $\mathrm{Fe}^{3+}$; and using a constant $\mathrm{K}_{\mathrm{D}}=0.3$ for the $\mathrm{Fe}^{2+/} \mathrm{Mg}$ exchange) until the melt is in equilibrium with mantle olivine (assumed to be $\mathrm{Fo}_{90}$ ). For the $\mathrm{H}_{2} \mathrm{O}$ content, we use the maximum concentration reported in melt inclusions from each vent. For samples $<500 \mathrm{ka}$ with no melt inclusion data, we used the average $\mathrm{H}_{2} \mathrm{O}$ content $(2 \mathrm{wt} \%)$ and $\mathrm{Fe}^{3+} / \mathrm{Fe}_{\mathrm{T}}(0.25)$ of the nearby vents from which we have melt inclusion data. For samples $>500 \mathrm{ky}$, which consist only of lavas unsuitable for melt inclusion volatile study (e.g., melt inclusions diffusively lose water in lava samples [Hauri, 2002; Portnyagin et al., 2008]), we assumed an average concentration of $\sim 1.5 \mathrm{wt} \%$ $\mathrm{H}_{2} \mathrm{O}$ and $\mathrm{Fe}^{3+} / \mathrm{Fe}_{\mathrm{T}}$ of $15 \%$. We used those values taking in consideration upper mantle-like trace elements (see more discussions below). An uncertainty of $1 \mathrm{wt} \% \mathrm{H}_{2} \mathrm{O}$ introduces a temperature uncertainty of $20^{\circ} \mathrm{C}$; and $10 \% \mathrm{Fe}^{3+} / \mathrm{Fe}_{\mathrm{T}}$ of $40^{\circ} \mathrm{C}$ and $0.3 \mathrm{GPa}$. Nevertheless, the $\mathrm{T}$ and $\mathrm{P}$ differences between samples $<500 \mathrm{ka}$ and samples $>500 \mathrm{ka}$ (below) cannot be explained by differences in $\mathrm{H}_{2} \mathrm{O}$ and $\mathrm{Fe}^{3+/} \mathrm{Fe}_{\mathrm{T}}$ (more details in Table S8 in the auxiliary material), but reflect distinct major element compositions (higher $\mathrm{MgO}, \mathrm{FeO}$ and lower $\mathrm{SiO}_{2}$ ) of the samples $>500 \mathrm{ky}$ compared to those $<500 \mathrm{ky}$ (Figure 4).

[30] The volcanics $>500 \mathrm{ka}$ include mostly the sequence of lavas exposed in Papoose Canyon
[Blondes et al., 2008] and the Oak Creek lavas that bear mantle xenoliths [Beard and Glazner, 1995; Lee et al., 2000; Blondes et al., 2007]. These $>500 \mathrm{ka}$ samples form an array extending from $\sim 1350^{\circ} \mathrm{C}$ and $2.2 \mathrm{GPa}(\sim 80 \mathrm{~km})$ to $1280^{\circ} \mathrm{C}$ and $1.7 \mathrm{GPa}(\sim 60 \mathrm{~km})$. Almost the entire variation is expressed in the Papoose sequence of lavas, with the earliest eruptives recording the highest $\mathrm{P}$ and $\mathrm{T}$ of mantle equilibration, and the latest ones recording the shallowest and coolest. Blondes et al. [2008] interpreted this to represent a single eruptive sequence, which could reflect efficient extraction of melt from over a $20 \mathrm{~km}$ depth range in the mantle. The calculated $\mathrm{P}$ and $\mathrm{T}$ derive from a clear increase in $\mathrm{SiO}_{2}$ (from $\sim 45-48 \mathrm{wt} \%$ ) and decrease in $\mathrm{FeO}$ (from $\sim 9.2-8.5 \mathrm{wt} \%$ ) at nearly constant $\mathrm{MgO}(9.5-$ $10.0 \mathrm{wt} \%$ ) from stratigraphic bottom to top in the sequence (Figure 4). Moreover, the interdependence of $\mathrm{T}$ and $\mathrm{P}$ within the Lee et al. [2009] thermobarometer leads to error arrays that parallel the Big Pine data, and it is possible that some of these variations may be correlated errors related to olivine addition. For these reasons, we consider here the average melting conditions for these lavas $\left(1320^{\circ} \mathrm{C} \pm 20^{\circ} \mathrm{C}\right.$ and $\left.2.0 \pm 0.2 \mathrm{GPa}\right)$.

[31] BPVF volcanics erupted over the past $500 \mathrm{ka}$ (which include all the scoria cones with melt inclusions reported here) record shallower and cooler melting conditions $\left(1190-1250^{\circ} \mathrm{C}\right.$ and $\left.55-30 \mathrm{~km}\right)$. These conditions overlap, but are slightly shallower than the $68-46 \mathrm{~km}$ melting column estimated by Wang et al. [2002], in a melting inversion that did not take into account $\mathrm{H}_{2} \mathrm{O}$ or $\mathrm{Fe}^{3+}$. Different cones appear to record distinct P-T conditions (Jalopy cone shallowest and Goodale Bee cone deepest), and so there may be structure within the array, but again we will just consider the average here $(1220 \pm$ $20^{\circ} \mathrm{C}$ and $1.1 \pm 0.2 \mathrm{GPa}$ or $38 \pm 7 \mathrm{~km}$ ).

[32] Taken together, all of the Big Pine magmas equilibrated at temperatures lower than the dry solidus of peridotite. This is consistent with the magmas containing 1.5-3.0 $\mathrm{wt} \% \mathrm{H}_{2} \mathrm{O}$, and so the melting process must be modeled with water. There are several recent parameterizations of wet melting, most of which follow a similar cryoscopic approach as outlined in Katz et al. [2003], Aubaud et al. [2004], and Langmuir et al. [2006]. Three parameters must be known: the cryoscopic effect $(\Delta T$ as a function of $\mathrm{H}_{2} \mathrm{O}$ concentration in the melt, at constant $\mathrm{F}$ ); the partition coefficient for $\mathrm{H}_{2} \mathrm{O}$ between bulk mantle solid and melt $\left(\mathrm{D}_{\mathrm{H} 2 \mathrm{O}}\right)$; and the melt productivity as a function of $\mathrm{T}(\mathrm{dT} / \mathrm{dF})$. Two recent studies provide updated expressions for these parameters for peridotite $+\mathrm{H}_{2} \mathrm{O}$ at a range of 


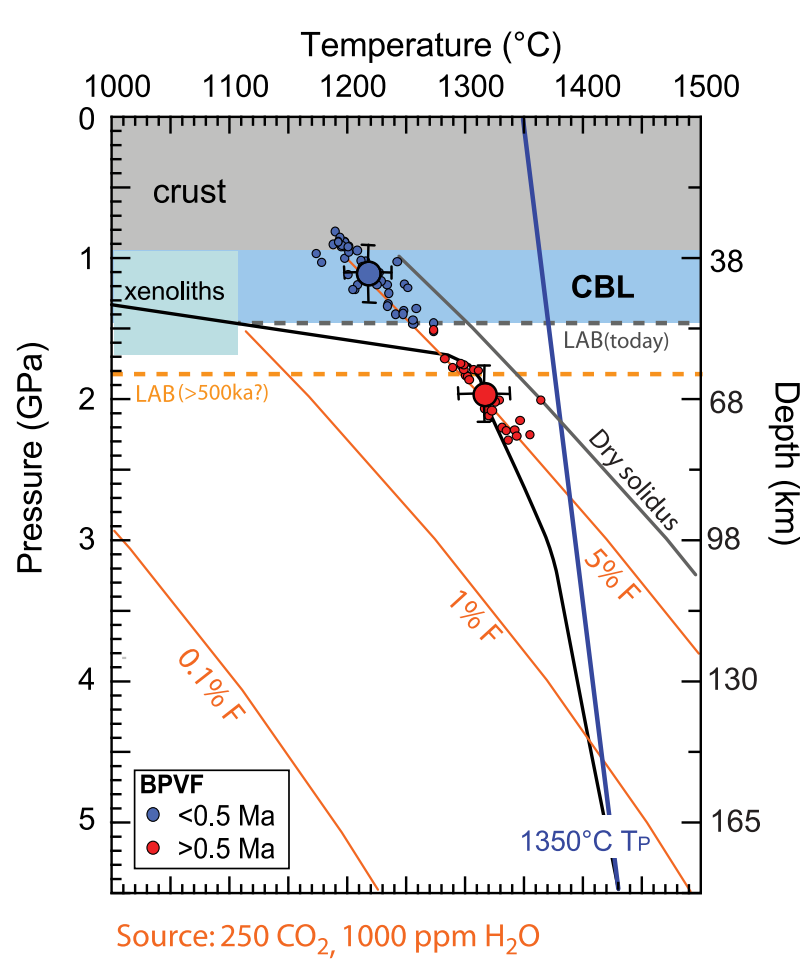

Figure 9. Melting conditions beneath the BPVF. Pressures and temperatures of equilibration are calculated from the peridotite-melt thermobarometer of Lee et al. [2009], using major element compositions and $\mathrm{H}_{2} \mathrm{O}$ contents of most primitive BPVF, differentiating samples $>0.5 \mathrm{Ma}$ (red) from those $<0.5 \mathrm{Ma}$ (blue). The thick blue line is for mantle potential temperature of $1350^{\circ} \mathrm{C}$. The black line combines an approximate conductive geotherm (assumed to be linear, steady state, passing through the xenolith field and extrapolating to $0^{\circ} \mathrm{C}$ at surface) with to a melting adiabat that intersects the $>500 \mathrm{ka}$ magma equilibration conditions near the inferred $>500 \mathrm{ka}$ LAB (orange dashed line). The range of lithospheric xenoliths are from Lee et al. [2000]. BPVF melting conditions can be reproduced by an average of 5\% melt fraction $(\mathrm{F})$ of a peridotite source with $250 \mathrm{CO}_{2}$, 1000 ppm $\mathrm{H}_{2} \mathrm{O}$ (using melting parameters as in Kelley et al. [2010] and Hirschmann [2010]). Although many other models are permissible for similar P-T conditions (e.g., 1\% melt of 300 ppm H2O mantle), the one illustrated is also consistent with the $\mathrm{Ce} / \mathrm{Y}$ discussed in the text. It is also likely that the melt fractions and source $\mathrm{H} 2 \mathrm{O}$ for the older and younger series magmas are different, but without data to guide the calculations for the older lavas, this is unconstrained. CBL, chemical boundary layer, $\mathrm{T}_{\mathrm{P}}=$ mantle potential temperature, dry solidus from Hirschmann [2000]. Depth calculated from pressure assuming a crustal density of 2.7 and mantle density of $3.3 \mathrm{~g} / \mathrm{cc}$.

relevant pressures [Kelley et al., 2010; Hirschmann, 2010], and predict similar melting conditions, with temperatures within $20^{\circ} \mathrm{C}$ of each other (Table S8). At least in theory, given such a model for wet melting, along with independent constraints on the pressure and temperature of melting (from thermobarometer) and $\mathrm{H}_{2} \mathrm{O}$ (from melt inclusion measurements), it is possible to determine uniquely the melt fraction and water content of the source for a given primitive basaltic liquid. The $>500$ ka lavas record $P$ and $T$ of equilibration that is $\sim 45$ degrees below the dry peridotite solidus, in melts that we assume have $\sim 1.5 \mathrm{wt} \% \mathrm{H}_{2} \mathrm{O}$, yielding $1-7 \%$ melting of mantle with $250-1150$ ppm $\mathrm{H}_{2} \mathrm{O}$ in the source, respectively. This range of solutions is derived from both the Kelley et al. [2010] and Hirschmann [2010] models, given $20^{\circ} \mathrm{C}$ uncertainty in temperature. The $<500$ ka magmas reflect $8-10 \%$ melting and 1500 $1900 \mathrm{ppm} \mathrm{H}_{2} \mathrm{O}$ in the source. Given the assumptions in $\mathrm{H}_{2} \mathrm{O}$ and $\mathrm{Fe}^{3+}$ in the older lavas, and in the mantle olivine composition ( $\mathrm{Fo}_{90}$ for both), and the high temperature sensitivity of the modes, these ranges in $\mathrm{F}$ and source $\mathrm{H}_{2} \mathrm{O}$ may not be robustly different for the two groups of magmas. Nonetheless, the data set as a whole forms a strikingly coherent array that parallels melting isopleths (Figure 9). Whether this reflects some fundamental aspect of the melting process, or is a fortuitous outcome of the modeling and thermobarometry, is not entirely clear.

\section{Discussion}

\subsection{The Water Content of the Mantle Beneath Big Pine}

[33] The significant water concentrations in primitive BPVF melts $\left(>1.5 \mathrm{wt} \% \mathrm{H}_{2} \mathrm{O}\right)$ require a source of water in the mantle. The results of the melting model yield a wide range of results, from $250 \mathrm{ppm}$ (at the upper end of MORB-OIB mantle, 100300 ppm [Dixon et al., 2002]) to $1900 \mathrm{ppm} \mathrm{H}_{2} \mathrm{O}$ (more typical of back-arc basins [Kelley et al., 2006]). Independent constraints come from a classic inversion of trace elements carried out by Ormerod et al. [1991] following the method in Hofmann and Feigenson [1983]. In such an inversion, the variations in a large suite of trace elements are assumed to be related by varying extents of partial melting, and the batch melting equation is co-solved for element pairs to provide an independent estimate of the relative partition coefficient and source concentration for each element. We can use their results to obtain an independent estimate of the $\mathrm{H}_{2} \mathrm{O}$ content of the source, based on their results for the REE. Taking into account different modal mineralogy (including garnet), Ormerod et al. [1991] predict an average $\mathrm{Ce} / \mathrm{Y}$ ratio of the mantle source of 1.4. 
We can arrive at a minimum Ce concentration in the BPVF source of $5.6 \mathrm{ppm}$ by assuming depleted mantle Y concentration of $4.1 \mathrm{ppm}$ [Salters and Stracke, 2004]. Given the restricted range in the $\mathrm{H}_{2} \mathrm{O} / \mathrm{Ce}$ ratio of Big Pine melt inclusions $(164 \pm$ 51 ), and the lack of fractionation between $\mathrm{H}_{2} \mathrm{O}$ and Ce during crystallization or melting of anhydrous pyroxenes and olivines [Hauri et al., 2006], we calculate a minimum $\mathrm{H}_{2} \mathrm{O}$ concentration in the Big Pine mantle of $925 \pm 280 \mathrm{ppm}$. This minimum estimation falls near the mid-range of the permissible $\mathrm{H}_{2} \mathrm{O}$ concentrations to satisfy the wet melting models above (i.e., $1075 \mathrm{ppm}$ ). Using the Ce source concentration above, and a $\mathrm{D}(\mathrm{Ce})$ of 0.015 (based on values in Kelemen et al. [2003]) and an average $\mathrm{Ce}$ concentration in Big Pine primary liquids of $97 \pm 18 \mathrm{ppm}$ for $>500 \mathrm{ka}$ volcanics and $78 \pm$ $30 \mathrm{ppm}$ for $<500 \mathrm{ka}$ volcanics (data from Blondes [2008] and this study, with olivine added until in equilibrium with $\mathrm{Fo}_{90}$ ), the degree of melting is calculated to be $4.3+0.9 /-1.3 \%$ and $5.8+4.5 /$ $-2.1 \%$, respectively. This range in melt fraction $(3.4-10.3 \%)$ not only is within the range of that calculated from the wet melting models (1-10 wt\%), but also provides a better-defined mean around 4-6\%. Thus, independent methods involving major, volatile and trace element data from lavas and melt inclusions, are consistent with average melting conditions beneath the BPVF involving mantle with $\sim 1000$ ppm $\mathrm{H}_{2} \mathrm{O}$ melting to $\sim 5 \% \mathrm{~F}$. There are likely real differences in $\mathrm{F}$ and source $\mathrm{H}_{2} \mathrm{O}$ with time, but given the uncertainties in the assumptions and models, we consider below only the implications of the average values.

[34] The above calculation provides a minimum $\mathrm{H}_{2} \mathrm{O}$ content of the BPVF mantle $(925+/-280 \mathrm{ppm})$ that rules out normal upper mantle as a source (100300 ppm $\mathrm{H}_{2} \mathrm{O}$ [Dixon et al., 2002]), and even exceeds the water storage capacity for nominally anhydrous minerals in the convecting upper mantle ( $<500$ ppm $\mathrm{H}_{2} \mathrm{O}$ [Hirschmann et al., 2009]). Thus, an additional source of water is required. There are several possibilities. One is crustal contamination. This seems unlikely at the BPVF, where melt inclusions with as much as $2 \mathrm{wt} \% \mathrm{H}_{2} \mathrm{O}$ occur in near primary $\mathrm{Fo}_{89}$ olivines (e.g., the ones from Jalopy). There is no correlation between the $\mathrm{H}_{2} \mathrm{O}$ content of melt inclusions, major elements, and Fo content of host olivines, as might be expected from a crustal assimilation process. Also, BPVF magmas bear mantle xenoliths [Ormerod et al., 1991; Beard and Glazner, 1995; Blondes et al., 2007; Kirby et al., 2008], and the lavas with clinopyroxene phenocrysts record mantle equilibration pressures [Mordick and
Glazner, 2006]. Therefore, BPVF magmas had minimal residence in the crust. We thus find the crust an unlikely source of the excess $\mathrm{H}_{2} \mathrm{O}$. Mantle lithosphere may also be considered a source of water, in the form of hydrous minerals like amphibole and phlogopite, but it is noteworthy that none of the mantle xenoliths from Big Pine contain any hydrous phases [Beard and Glazner, 1995]. Moreover, our new water data for lithospheric mantle peridotite xenoliths demonstrate unusually dry mantle lithosphere beneath Big Pine, with bulk $\mathrm{H}_{2} \mathrm{O}$ contents $(<75$ ppm; Figure 7) well below any of the above estimates (250-1900 ppm) for the melt source. Indeed, the mantle lithosphere beneath Big Pine appears to have been cold and dry, which may be why it has survived as an isotopically distinct layer since perhaps the Proterozoic [Beard and Glazner, 1995; Lee et al., 2000].

[35] We suggest that the excess water recorded in Big Pine magmas derives from the sub-lithospheric mantle. In fact, at the temperatures inferred for magma formation, mantle that contains significant water is weak and will flow as asthenosphere [Hirth and Kohlstedt, 1996; Karato and Jung, 1998; Karato, 2003]. There are three possibilities for the source of excess water in the mantle beneath Big Pine: hydrous minerals in the asthenosphere, subducting oceanic crust and the transition zone. Phlogopite is a Mg-rich mica and K-richterite is a K-rich amphibole, both of which contain $\mathrm{wt} \%$ concentrations $\mathrm{H}_{2} \mathrm{O}$ in their structures and may be stable at pressures $>4 \mathrm{GPa}$ along a normal adiabat $\left(\mathrm{Tp}=1350^{\circ} \mathrm{C}\right)$ in the upper mantle [Trønnes, 2002]. Phlogopite in the mantle beneath Big Pine may be responsible for the high time-integrated $\mathrm{Rb} / \mathrm{Sr}$ reflected in the high ${ }^{87} \mathrm{Sr} /{ }^{86} \mathrm{Sr}$ of the Big Pine magmas [Ormerod et al., 1991], and in the source of potassic volcanism that occurred in the Pliocene of the southern Sierras [Farmer et al., 2002]. On the other hand, both phlogopite and K-richterite have a diagnostic $\mathrm{H}_{2} \mathrm{O} / \mathrm{K}_{2} \mathrm{O}$ ratio of 0.38 (from stoichiometry) that can be used to test for their presence in the source of BPVF magmas. In a plot of $\mathrm{H}_{2} \mathrm{O} / \mathrm{K}_{2} \mathrm{O}$ vs $1 / \mathrm{K}_{2} \mathrm{O}$ [after Wallace and Anderson, 1998], BPVF melt inclusions appear to mix to phlogopite-Krichterite for the more K-rich end-member, but they clearly mix to another, higher $\mathrm{H}_{2} \mathrm{O} / \mathrm{K}_{2} \mathrm{O}$ component that is not part of the normal N-MORB-E-MORB array (Figure 10a). Arcs and back-arc basin magmas plot to very high $\mathrm{H}_{2} \mathrm{O} / \mathrm{K}_{2} \mathrm{O}(>7)$ and may relate to the other end-member. Thus, while phlogopite-Krichterite may exist in the source of BPVF magmas, another water source is still required. 

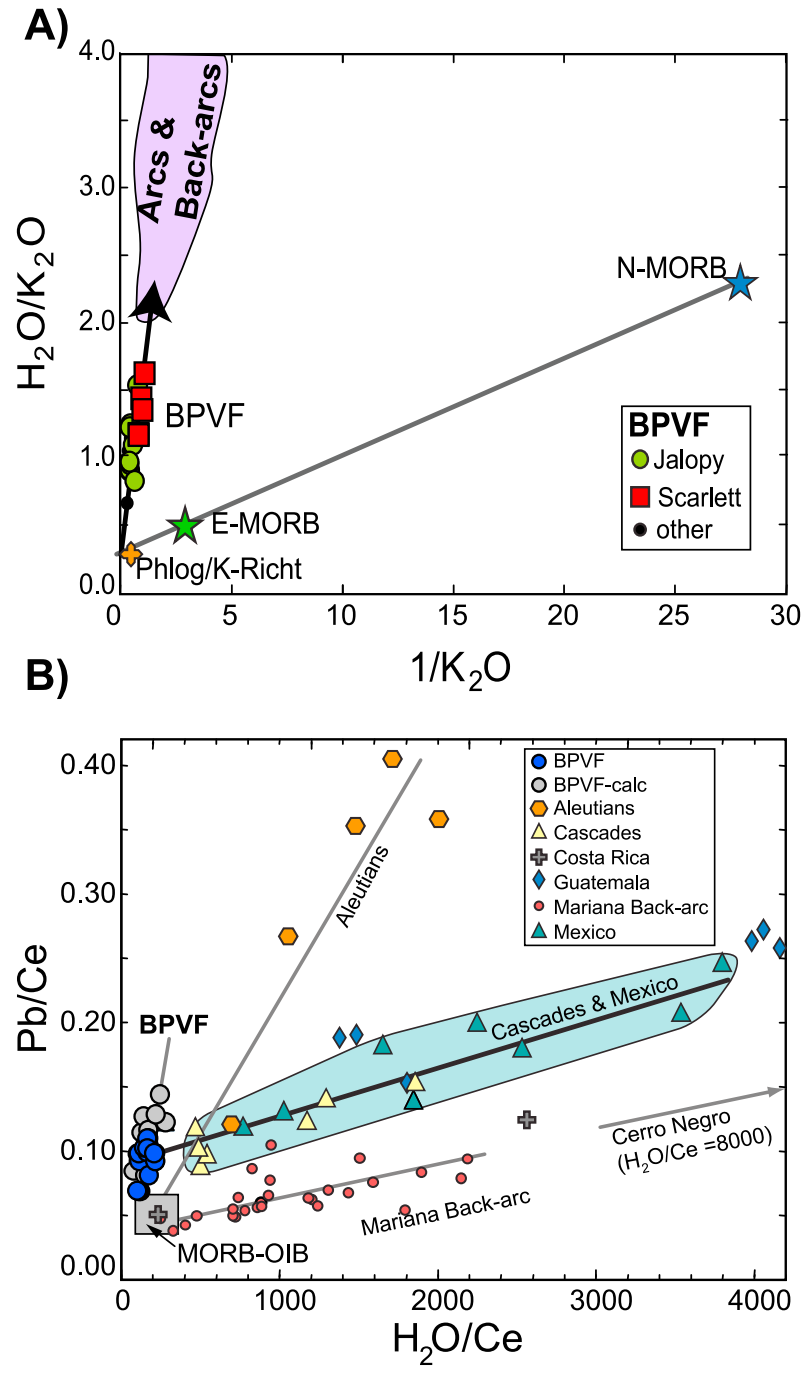

Figure 10. Geochemical constraints on the source of water in BPVF magmas. (a) $\mathrm{H}_{2} \mathrm{O} / \mathrm{K}_{2} \mathrm{O}$ versus $1 / / \mathrm{K}_{2} \mathrm{O}$ systematics [after Wallace and Anderson, 1998] suggest mixing between a deep volatile rich phase (Phlogopite/ $\mathrm{K}$-Richterite) and an arc source for BPVF melt inclusions. (b) Melt inclusions from active volcanic arcs have uniformly higher $\mathrm{Pb} / \mathrm{Ce}$ and $\mathrm{H}_{2} \mathrm{O} / \mathrm{Ce}$ than MORB-OIB, generally ascribed to a $\mathrm{H}_{2} \mathrm{O}-\mathrm{Pb}$ rich slab fluid or melt. Melt inclusions from the BPVF have high $\mathrm{Pb} / \mathrm{Ce}$ like some arcs, but lower $\mathrm{H}_{2} \mathrm{O}$ /Ce than most MORB-OIB. Some continental arcs (Cascades-Mexico) mix toward a mantle end-member with a high $\mathrm{Pb} / \mathrm{Ce}$ like the BPVF. Blue circles are least degassed melt inclusions from BPVF (as in Figure 6). Gray circles include $\mathrm{H}_{2} \mathrm{O}$ calculated from $\mathrm{Cl}$ and $\mathrm{H}_{2} \mathrm{O} / \mathrm{Cl}=66$ (as in Figure 6). Arc and back-arc data from Gribble et al. [1996]; Sadofsky et al. [2008]; Johnson et al. [2009]; Zimmer et al. [2010]; and Ruscitto et al. [2010].
[36] As discussed above, the $\mathrm{H}_{2} \mathrm{O}$ contents of Big Pine magmas approach those typical of back-arc basin basalts, where water is actively supplied from subduction zones [e.g., Kelley et al., 2006]. Indeed, BPVF melt inclusions plot in a distinct region on a $\mathrm{H}_{2} \mathrm{O} / \mathrm{Ce}-\mathrm{Pb} / \mathrm{Ce}$ diagram, with $\mathrm{H} 2 \mathrm{O} / \mathrm{Ce}$ similar to upper mantle asthenosphere (MORB-OIB), but with clearly higher $\mathrm{Pb} / \mathrm{Ce}$, like volcanic arcs. Interestingly, continental arcs like the Cascades, Guatemala, and Mexico plot toward a mantle end-member with $\mathrm{Pb} / \mathrm{Ce}$ higher than MORB-OIB, in the range of our new data from the BPVF (Figure 10b).

[37] The trace element signatures of Big Pine magmas also share similarities with arc magmas (i.e., excess $\mathrm{Pb}$, depletions in $\mathrm{Nb}$ and Ta; Figure 5). The dehydration of subducted material along slab P-T paths is an obvious supply of water to mantle above subducted slabs, but there is no subduction zone beneath Big Pine at this time. On the other hand, the shear wave tomography in Figures 11a and $11 \mathrm{~b}$ illuminates the Isabella Anomaly, a prominent fast seismic anomaly located immediately to the west of the Sierra Nevada and BPVF. The Isabella Anomaly has been interpreted as actively foundering Sierran lithospheric mantle or lower crust [e.g., Zandt et al., 2004; Frassetto et al., 2011], or as a fragment of the Farallon Plate that did not detach [Pikser et al., 2012; Y. Wang et al., Fossil slabs attached to unsubducted fragments of the Farallon Plate, submitted to Nature Geoscience, 2012]. This feature could drive mantle upwelling and melting, either as counterflow to the foundering drip, or induced flow as it is dragged northwest with the Pacific Plate. The Isabella Anomaly is one of the largest seismic anomalies in the western USA, comparable in magnitude to the actively subducting Gorda Plate to the north [Schmandt and Humphreys, 2010, 2011]. It is also possible this feature is still dehydrating, although subduction ceased at $20 \mathrm{Ma}$. In subduction zones, the $\mathrm{K}_{2} \mathrm{O} / \mathrm{H}_{2} \mathrm{O}$ and $\mathrm{H}_{2} \mathrm{O} / \mathrm{Ce}$ of slab fluids is related to their last temperature of equilibration at the slab surface [Plank et al., 2009]. Interpreted in this way, the Isabella slab fluids would fall at the high temperature end $\left(>950^{\circ} \mathrm{C}\right)$ of fluids that supply active subduction zones, consistent with the heating up of this slab remnant during long residence in the mantle.

[38] Another possible source of water beneath Big Pine is from mantle that may upwell from the transition zone. The storage capacity of water in transition zone minerals is considerably higher $(0.5-1 \mathrm{wt} \%$ [Ohtani, 2005]) than in the convecting upper mantle $\left(<500 \mathrm{ppm} \mathrm{H}_{2} \mathrm{O}\right.$ [Hirschmann et al., 2009]) and so mantle that upwells from the 
A)
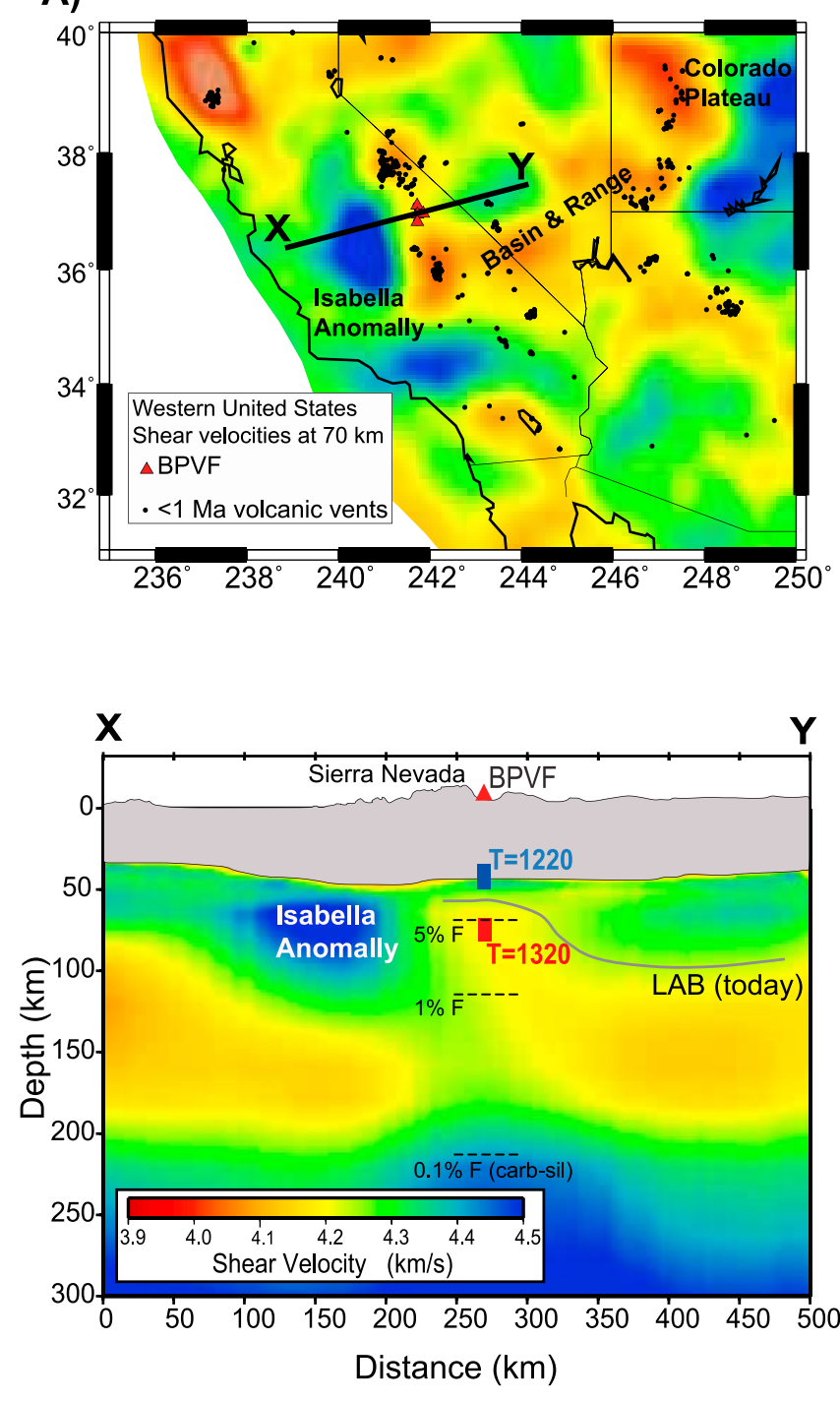

B)

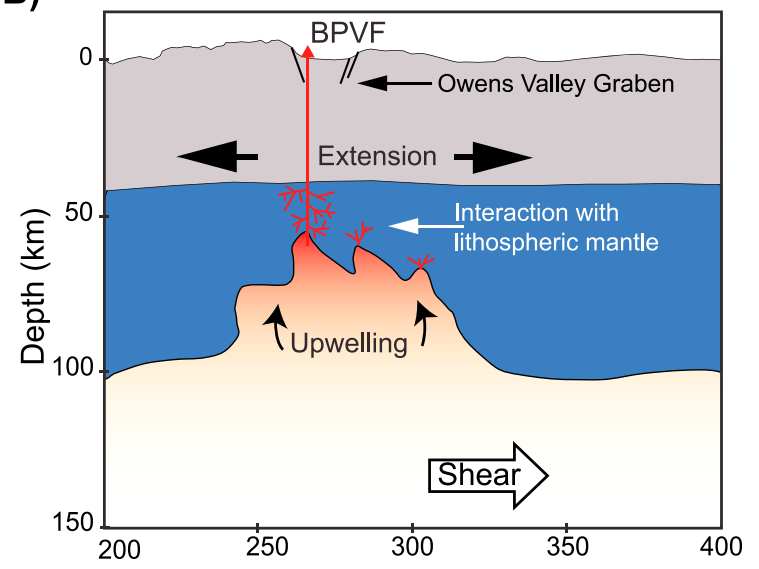

C)

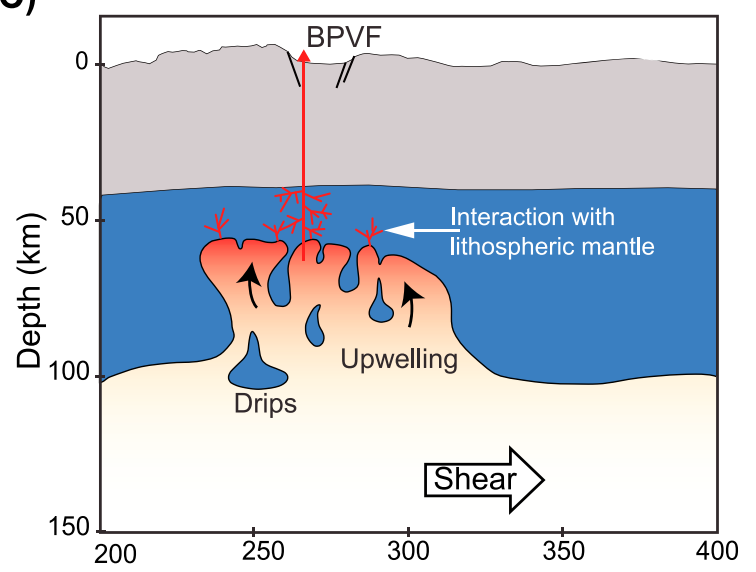

D)

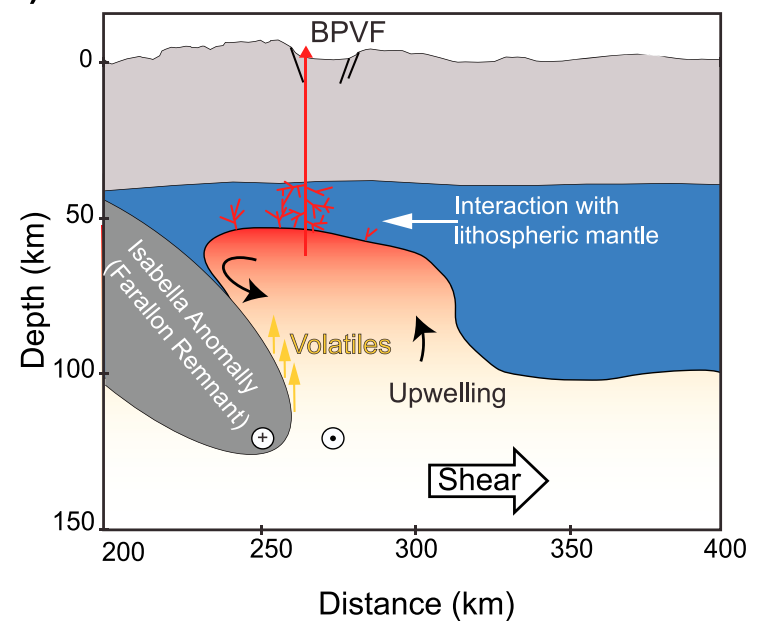

Figure 11. Surface wave tomography beneath the Basin and Range and possible dynamic melting models for the BPVF. (a) Shear velocities at $70 \mathrm{~km}$ depth from Rayleigh-wave surface tomography [Rau and Forsyth, 2011]. Note the prominent Isabella Anomaly adjacent to BPVF. Melting contours and BPVF melt equilibration depths (red and blue bars) from Figure 9. LAB is the lithosphere-asthenosphere boundary deduced from the shear-velocity structure. Melting beneath the BPVF driven by (b) Extension-melt feedback, (c) small-scale convection related with lithospheric delamination and (d) the Isabella Anomaly as a slab remnant and small-scale convection related with it (see text for discussion). Mantle shear direction from Conrad et al. [2010]. 
transition zone will likely melt [Bercovici and Karato, 2003]. Assuming the maximum water storage, these melts will be water rich $(>17 \mathrm{wt} \%$ $\mathrm{H}_{2} \mathrm{O}$ [Hirschmann et al., 2009]), and may ascend and supply water to the primary melting region beneath BPVF. Although there is no obvious dynamic reason why mantle might upwell from the transition zone beneath Big Pine, the high water contents in magmas throughout the Basin and Range [Plank et al., 2009] may require it, and mantle convection models may predict it as part of a large counterflow to Farallon downwelling [Moucha et al., 2008].

\subsection{Implications of the Pressure and Temperature Estimates for Rheological Boundaries of Melt Equilibration}

[39] Although mantle-melt thermobarometry provides valuable quantitative constraints on conditions within the upper mantle, the single pressure and temperature recorded in each magma composition is not always straightforward to connect to a melting process. One possibility is that magmas reflect only the final $\mathrm{P}$ and $\mathrm{T}$ of equilibration in the mantle. Melting prior to this point may have proceeded as a batch (melt remains with solid) or fractional (melt separates from solid) process, but if melt aggregates and equilibrates in one region, it will only reflect the final conditions. The other possibility is that the P-T recorded by magmas reflects a mean of the melts that have equilibrated at different depths. We find this latter scenario unlikely for the $<500 \mathrm{ka}$ BPVF magmas, given their very shallow pressures of equilibration $(1.1 \mathrm{GPa}$ or $38 \pm 7 \mathrm{~km}$, essentially at the Moho) and the lack of garnet signature in the magmas, meaning at least, that the contribution of deep melts to the mixture is minor.

[40] The pressures recorded in both series of melts may correspond to mechanical boundaries in the melting region. One is the lithosphere-asthenosphere boundary (LAB), which is unusually shallow, $\sim 55-$ $60 \mathrm{~km}$ as deduced from the maximum gradient in the shear velocity profile (Figure 11). Although the relatively high velocity (lithospheric) layer immediately beneath the Moho is too thin to be well resolved from the surface wave tomography alone [Rau and Forsyth, 2011], there is an apparent negative Ps conversion beneath Big Pine observed at $\sim 55 \mathrm{~km}$ from receiver function analysis [Frassetto et al., 2011], also consistent with a shallow LAB. This boundary fundamentally separates the depths of equilibration of the two age groups of magmas.
The older magmas ( $>500 \mathrm{ka})$ equilibrated at $>65 \mathrm{~km}$ (70 km on average), possibly stalling at an older, slightly deeper LAB, at that time. The younger magmas $(<500 \mathrm{ka})$ equilibrated uniformly above this boundary, in the inferred lithosphere, and on average at $38 \pm 7 \mathrm{~km}$, which is equivalent to crustal thickness here (of $\sim 36 \mathrm{~km}$ ) determined from receiver function analysis [Frassetto et al., 2011]. Thus, the older magmas equilibrated within asthenosphere, possibly at the base of an earlier $\sim 70 \mathrm{~km}$ LAB, while the younger magmas have equilibrated above the modern $\sim 55 \mathrm{~km} \mathrm{LAB}$, on average at depths close to the Moho. This is consistent with the fact that both the LAB and Moho are rheological or density boundaries, which may promote melt stalling and equilibration of melts that may have initiated at a much deeper solidus.

[41] It is important to consider that the younger magmas, which have equilibrated in the lithosphere near the Moho, clearly did not form there, as their temperatures are too high $\left(1220^{\circ} \mathrm{C}\right)$ to sustain at the Moho without massive melting of the crust. Also, their temperatures exceed those recorded by the Oak Creek mantle xenoliths, $1000-1100^{\circ} \mathrm{C}$ at $<1.5 \mathrm{GPa}$ as reported by Lee et al. [2001] (although Ducea and Saleeby [1996] report up to $1200^{\circ} \mathrm{C}$ ). Moreover, the lithosphere is too dry to be the source of these magmas, as recorded in the low water contents $\left(<100 \mathrm{ppm} \mathrm{H}_{2} \mathrm{O}\right)$ of the Oak Creek xenoliths (Figure 7), and the lack of hydrous minerals contained within them [Beard and Glazner, 1995]. Thus, the extent of re-equilibration within the lithosphere is partial, reflected in the pressures (which only requires precipitation of olivine), but not the temperatures (which is retained in the transported melts) nor water contents (which would require equilibration with larger volumes of dry mantle). It is also important to keep in mind that the seismic results represent averages over significant areas; very localized thinning or erosion or infiltration of the lithosphere by melt would not be recognized.

\subsection{Geochemical Indicators of Lithosphere Versus Asthenosphere Mantle Sources in the Evolution of BPVF}

[42] Our thermobarometry results, in combination with the seismic structure of the upper mantle, point to different melt equilibration scenarios for the older and younger BPVF suites, with the $>500 \mathrm{ka}$ magmas equilibrating below the LAB in the asthenosphere, and the $<500 \mathrm{ka}$ magmas equilibrating within the lithosphere. This interpretation differs from previous work that considered all Big Pine 
A)

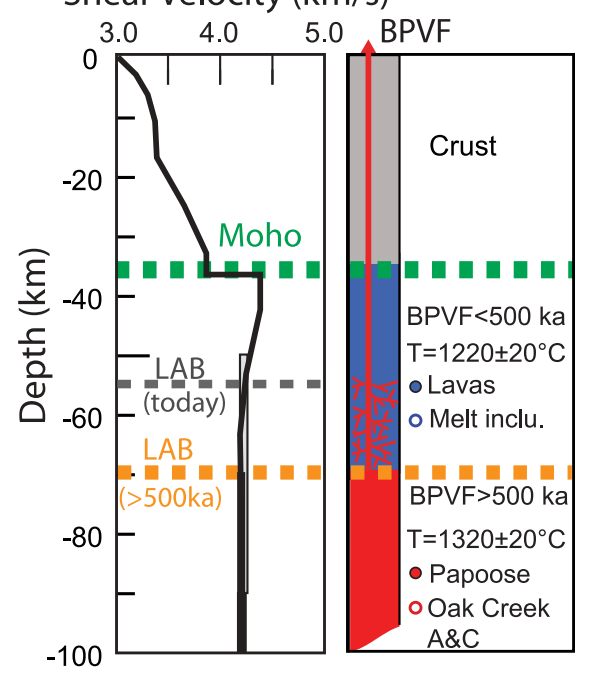

B)

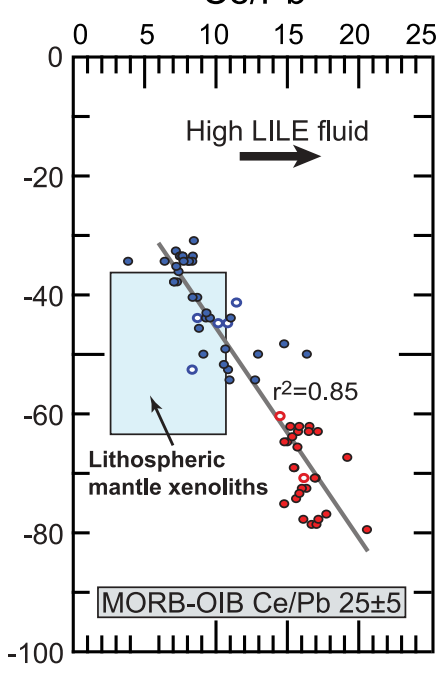

C)

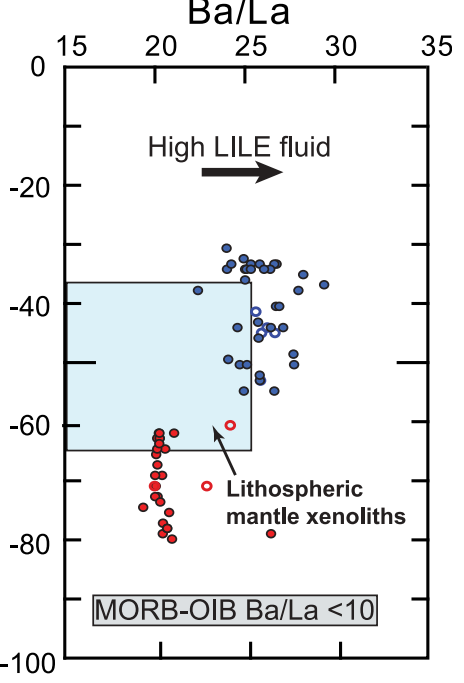

Figure 12. Shear wave velocity profiles compared with depth of melt equilibration and the geochemical evolution of BPVF. (a) Shear wave profile (from Rau and Forsyth [2011], Rayleigh-wave inversion) and depth of equilibration for $<500 \mathrm{ka}$ and $>500 \mathrm{ka}$ BPVF melts. (b) Strong correlation between melting depths and the $\mathrm{Ce} / \mathrm{Pb}$ ratio in BPVF melt inclusions and volcanics. The ratio decreases with time, toward values more typical of lithospheric mantle xenoliths [from Lee, 2005] and subduction zone magmas. (c) Melts $>500$ ka have constant $\mathrm{Ba} / \mathrm{La} \sim 20$, closer to upper asthenosphere values, while the samples of $<500 \mathrm{ka}$ melts have higher and variable $\mathrm{Ba} / \mathrm{La}(25-30)$, also approaching subduction zone magmas. These strong correlations between trace element ratios and melt depths delineate a thin chemical boundary layer in the upper mantle that may coincide with the seismic LAB. With time, melts interact more extensively with this shallow lithosphere. Upper asthenosphere (MORB-OIB) values from Georoc database (http://georoc.mpch-mainz.gwdg.de/georoc/).

magmas to have a lithospheric source, based on their Proterozoic Sm-Nd model ages, their high ${ }^{87} \mathrm{Sr} /{ }^{86} \mathrm{Sr}(0.7054-0.7064)$, and their arc- or continent-like trace element signatures [Ormerod et al., $1988,1991]$. On the other hand, based on our new data here and that in Blondes et al. [2008], we find a systematic variation in diagnostic trace element ratios in both space and time. The hotter and deeper melts $(>0.5 \mathrm{Ma})$ have higher $\mathrm{Ce} / \mathrm{Pb}(14-21)$ and constant $\mathrm{Ba} / \mathrm{La} \sim 20$ values, closer to an upper mantle asthenosphere end-member (Figures 12a and $12 \mathrm{~b})$. Shallower and cooler melts $(<0.5 \mathrm{Ma})$ have lower $\mathrm{Ce} / \mathrm{Pb}(<14)$, and higher $\mathrm{Ba} / \mathrm{La}(25-30)$ values, more typical of arc magmas and consistent with the available data from lithospheric mantle xenoliths from BPVF [Lee, 2005], suggesting a lithosphere component for these melts (Figures 12a and $12 \mathrm{~b}$ ). In the data set as a whole, there is a highly significant $\left(\mathrm{R}^{2}=0.85\right)$ correlation between $\mathrm{Ce} / \mathrm{Pb}$ and the depth of equilibration, from 90 to $35 \mathrm{~km}$. Thus there is a clear contribution from old, chemically distinct mantle that increases at shallower levels, consistent with a chemical boundary layer above the seismically imaged LAB (55-60 km depth, Figures $11 \mathrm{~b}$ and 12a). On the other hand, the temperatures $\left(>1200^{\circ} \mathrm{C}\right)$ and water contents $\left(>1.5 \mathrm{wt} \% \mathrm{H}_{2} \mathrm{O}\right)$ of all the magmas seem inconsistent with formation in the cold and "dry" lithosphere.

[43] Although the correlation is clear with trace elements $(\mathrm{Ce} / \mathrm{Pb}, \mathrm{Ba} / \mathrm{La})$, isotopic compositions do not vary systematically with depth, except within the Papoose section [Blondes et al., 2008]. The petrologic modeling together with the trace element correlations collectively suggest that both asthenosphere and lithosphere have played a role, and possibly evolved, over the formation of the BPVF magmas. It is possible that mantle interpreted as asthenosphere today (at 90 to $60 \mathrm{~km}$ depth from shear wave tomography in Figure 11b) was evolved from lithospheric mantle during melt infiltration and re-heating, thus explaining the old model ages of all BPVF magma sources [Beard and Glazner, 1995].

\subsection{The Cause of Mantle Melting at Big Pine}

[44] Together, the petrological and seismological data provide a consistent view of the melting region beneath Big Pine. The base of the low velocity zone is around $225 \mathrm{~km}$ beneath Big Pine (Figure 11b), 
which could correspond to the carbonatite-carbonated silicate melt transition [after Hirschmann, 2010]. This would occur at $\sim 8 \mathrm{GPa}(250 \mathrm{~km})$ for mantle with $1000 \mathrm{ppm} \mathrm{H}_{2} \mathrm{O}$ and $250 \mathrm{ppm} \mathrm{CO}_{2} \mathrm{~km}$ and $\mathrm{F}=$ $0.1 \%$ (note that primary $\mathrm{CO}_{2}$ is generally not possible to constrain even from melt inclusions, which may already be saturated in a $\mathrm{CO}_{2}$-rich vapor when trapped; $250 \mathrm{ppm} \mathrm{CO}_{2}$ in the mantle is twice that needed to explain maximum $\mathrm{CO}_{2}$ contents in BPVF magmas, and so permissible and not unreasonable). The region of the lowest seismic velocities beneath Big Pine $(<4.2 \mathrm{~km} / \mathrm{s})$ begins at around $120 \mathrm{~km}$, which could correspond to the onset of significant silicate melting $(\mathrm{F}=1 \%$ in mantle with $1000 \mathrm{ppm}$ $\mathrm{H}_{2} \mathrm{O}$ at $\left.4 \mathrm{GPa}, 140 \mathrm{~km}\right)$. Melting then continues up to the base of the $500 \mathrm{ka} \mathrm{LAB}(\sim 70 \mathrm{~km})$, producing $\sim 5 \%$ melt. Although the melting boundaries are tens of $\mathrm{km}$ deeper than the seismic boundaries, these differences are not likely significant given the uncertainties in both inversions. The $>500 \mathrm{ka}$ magmas then erupted rapidly above this depth, possibly by diking in cold lithosphere, carrying mantle xenoliths to the surface, with little residence in the crust. With time, the mantle lithosphere warms, magmas stall, react and equilibrate there. This leads to an erosion of the lithosphere, and possibly shallowing of the LAB from 70 to $55 \mathrm{~km}$ in $\sim 500 \mathrm{ka}$. Crustal storage regions are likely near the brittleductile transition $(\sim 20 \mathrm{~km})$, where magmas stall due to a rheological contrast, melt inclusions start to be trapped by crystal cooling (at $\leq 5 \mathrm{~kb}$; Figure 6), magmas fractionate, and no longer bear mantle xenoliths. Volcanic vents form very near active faults in Owens Valley [Kirby et al., 2008], which enhanced ascent pathways.

[45] Despite this self-consistent view of the melting process, many questions still remain as to the ultimate cause of volcanism here. Why do mafic magmas erupt at Big Pine? What is special about the crust and mantle that leads to melting and eruption? There are many special tectonic features and events that appear to characterize the Big Pine region. (1) Active oblique strike-slip faulting and extension in Owens Valley [Phillips and Majkowski, 2011]; (2) proposed Pliocene foundering of adjacent Sierran lithosphere [Manley et al., 2000; Jones et al., 2004; Zandt et al., 2004]; (3) and the prominent Isabella anomaly to the west and thicker LAB to the east (Figure 11b). Which of these are the critical drivers for melting and eruption of mafic magmas here? And how can they be consistent with the constraints we have provided on the pressures, temperatures, water contents and evolution of the mantle melting region? We provide two views on melting, one top-down (1. Extension-Melt Feedback) and the other bottom-up (2. Small-Scale Convection).

[46] 1. Extension-melt feedback. In the first view, lithospheric extension is the initial driver for melting and eruption. Owens Valley, where Big Pine magmas erupt, is a graben that has developed largely since $3.5 \mathrm{Ma}$, with active normal and oblique strike slip faults [Phillips and Majkowski, 2011]. Most of the modern motion across the valley (determined geodetically) drives strike-slip on N-S faults, although as much as a third of the total motion is driving extension at a rate of $\sim 1.5 \mathrm{~mm} / \mathrm{yr}$ [Phillips and Majkowski, 2011]. Applied over the past $3.5 \mathrm{Ma}$, this extension could account for $\sim 5 \mathrm{~km}$ of opening in Owens Valley. Although active and significant, this extension $(1.5 \mathrm{~km} / \mathrm{Ma})$ is more than an order of magnitude too small to drive either the above proposed LAB shallowing $(30 \mathrm{~km} / \mathrm{Ma})$ or the apparent regional-scale thinning of the LAB from $90 \mathrm{~km}$ to the east of Big Pine to $55 \mathrm{~km}$ beneath it (Figure 11b). On the other hand, it is possible that feedbacks between thinning and melting lead to progressive conversion of lithosphere to asthenosphere, in a thermal and chemical corrosion process similar to that outlined by Holtzman and Kendall [2010]. Initial extension leads to some enhanced melt production below the $\mathrm{LAB}$, followed by melt infiltration, reaction and diking within the lithosphere that cause it to weaken and thin further. Further melting leads to additional feedbacks as lithosphere topography drives stress-driven melt segregation [Holtzman and Kendall, 2010] or sheardriven upwelling [Conrad et al., 2010, 2011], which leads to further corrosion, thinning, and eventually upwelling and decompression melting. It is possible this process commenced at $3.5 \mathrm{Ma}$, coinciding with the onset of the current strain regime in Owens Valley, and that $\sim 2 \mathrm{Ma}$ were necessary for lithosphere-to-asthenosphere conversion to progress to a critical stage for melting, segregation and eruption of the first Big Pine magmas at 1.3 Ma. Today, asthenospheric melts have been generated up to $\sim 60 \mathrm{~km}$ depth, above which the lithosphere is actively being infiltrated and warmed. Melts are now equilibrating there, and no longer diking through this region.

[47] This view of the origin of the BPVF fundamentally relates melting to active lithospheric deformation. Deformation initiates upwelling that drives melting and starts a feedback process that also creates melt pathways to the surface. The broader implication here is that magmas in the Basin and Range will tend to form and erupt where deformation is active. This is true in a broad sense 
(most of modern Basin and Range deformation and volcanism is occurring at its margins; along the eastern side of the Sierras (as in Big Pine) and along the western side of the Colorado Plateau [Bennett et al., 1998; Hammond and Thatcher, 2004]. Moreover, seismic images are providing abundant evidence for the presence of melt in the mantle over much of the Western USA, but in most places, it does not manifest at the surface (e.g., in the Amagmatic Zone of southern Nevada [Rau and Forsyth, 2011]), possibly because active deformation does not provide the melt enhancement, segregation and ascent pathways required for eruption. Further work linking melting in the mantle to surface deformation and volcanism across the Basin and Range will test these ideas. On the other hand, this view of deformation and melting does not provide a ready source of the excess water that is required in the source of Big Pine magmas. Normal Farallon subduction did occur in this region as recently as $18-20 \mathrm{Ma}$, and likely hydrated the mantle, but as we have argued above, the water concentration reflected in the source of Big Pine exceeds the normal storage capacity of anhydrous mantle at $\mathrm{T}_{\mathrm{P}}=1350^{\circ} \mathrm{C}$ (500 ppm), and phlogopite, which can be stable at these temperatures, cannot supply all the water (based on $\mathrm{K}_{2} \mathrm{O} / \mathrm{H}_{2} \mathrm{O}$, Figure 10).

[48] 2. Small-scale convection. The other driver of melting could be related to lithospheric drips and the Isabella anomaly to the west of the BPVF (Figures 11c and 11d). The Isabella anomaly is a fast seismic anomaly that extends to at least $200 \mathrm{~km}$ depth, and is located beneath the western Sierra foothills and Great Valley. Its origin is debated. Some ascribe it to Sierran lithosphere (garnet clinopyroxene lower crust and peridotitic mantle) that foundered in the Pliocene [Zandt, 2003; Ducea and Saleeby, 1998; Jones et al., 2004] while others link it to the fossil Monterey microplate, a remnant of the Farallon Plate that was left when subduction ceased $\sim 20 \mathrm{Ma}$ (Wang et al., submitted manuscript, 2012). In the latter view, the Isabella anomaly is a slab fragment, still attached to the Pacific lithosphere, and possibly being dragged northwest along with it. In either case, a sinking or dragging structure (lithospheric drips or remnant subducting oceanic crust) may induce flow in surrounding mantle, either in an upward counterflow or in a small-scale convective circulation, in combination with the high mantle shear in the western Basin and Range [Zandt et al., 2004; Elkins-Tanton et al., 2001; Conrad et al., 2010]. It is also possible that the Isabella anomaly could supply excess water to the mantle melting beneath Big Pine, through heating-induced dehydration of hydrous Sierran lower crust or of hydrous Farallon slab. In this view, the thin LAB beneath Big Pine was not generated by extension, but by lithospheric foundering in the Pliocene, and melting occurs today due to an influx of water and convective upwelling. In this way, the BPVF is situated above a long-lived mantle wedge, like an arc, a southern extension of the ancestral Cascades (sensu [Cousens et al., 2008]). Although it is unclear whether Mesozoic arc crust or a slab subducted 20 my ago could retain enough water to supply the BPVF, the Isabella anomaly does appear spatially related to volcanism along its eastern margin, from Long Valley to Coso. On the other hand, this volcanism does not include the high-Mg\# andesite compositions of bajaites erupted in the south, where similar Guadalupe and Magdalena Farallon remnants have been proposed (Wang et al., submitted manuscript, 2012), nor the much lower ${ }^{87} \mathrm{Sr} /{ }^{86} \mathrm{Sr}$ of the ancestral or modern Cascades erupted in the north and related to Gorda and Juan de Fuca subduction [Cousens et al., 2008]. The isotopic composition of Big Pine magmas overlaps that of Sierra Nevada granites. The role of the Isabella anomaly as a water source remains to be tested by study of the water contents across the Basin and Range, to see how widespread or locally "wet" the mantle is.

\section{Conclusions}

[49] Big Pine melt inclusions record surprisingly high $\mathrm{H}_{2} \mathrm{O}$ contents from 1.5 to $\sim 3$ wt. $\%$, with a degassing/eruption path from $>5 \mathrm{~kb}(\sim 20 \mathrm{~km})$ to the surface. Estimates of the oxidation state also indicate high $\mathrm{Fe}^{3+}$ contents $\left(23-30 \% \mathrm{Fe}^{3+} / \mathrm{Fe}_{\mathrm{T}}\right)$, approaching the most oxidized arc magmas. On the other hand, lithospheric mantle xenoliths from the well-known Oak Creek location at Big Pine record water contents below $75 \mathrm{ppm}$, indicative of a dry lithosphere. Given a calculated mantle source of $\sim 1000$ ppm $\mathrm{H}_{2} \mathrm{O}$ for BPVF primary melts, the source of the water must be sub-lithospheric. Certain aspects of Big Pine magma chemistry resemble subduction zone magmas (e.g., $\mathrm{Pb}$ and $\mathrm{Nb}$ anomalies), while others do not (e.g., $\mathrm{H}_{2} \mathrm{O} / \mathrm{Ce} ;{ }^{87} \mathrm{Sr} /{ }^{86} \mathrm{Sr}$ ). One possibility is that the nearby prominent Isabella seismic anomaly is a Farallon slab remnant or lithospheric drip that supplied water to the region.

[50] The BPVF samples also record a shallowing of mantle-melt equilibrium over the past $0.5 \mathrm{ka}$, from $2 \mathrm{GPa}(65-70 \mathrm{~km})$ and $1320^{\circ} \mathrm{C}$ to $1 \mathrm{GPa}(35-40 \mathrm{~km})$ and $1220^{\circ} \mathrm{C}$. The depths of melting are also strongly 
correlated with a shift over time to trace element ratios $(\mathrm{Ce} / \mathrm{Pb}$ and $\mathrm{Ba} / \mathrm{La})$ diagnostic of subduction or lithospheric sources. Taken together, the magmas record asthenospheric melting deeper than $70 \mathrm{~km}$ during the early phase of volcanism, and shallower melt equilibration in a chemical boundary layer reflected in the more recent magmas. A strictly lithospheric source of the $<0.5 \mathrm{Ma}$ melts can be ruled out based on the high temperatures and water contents of the melts relative to the demonstrably lithospheric mantle xenoliths. Melt infiltration is thus a potentially important mechanism in affecting melt composition and in converting lithosphere to asthenosphere. The lack of a fast seismic lid in the mantle beneath Big Pine is consistent with the P-Tmelting history recorded in the magmas, initiating as deep as $200 \mathrm{~km}$ in volatile-rich upwelling mantle asthenosphere $\left(\mathrm{Tp} \sim 1350^{\circ} \mathrm{C}\right)$, infiltrating a $30 \mathrm{~km}$ thick chemical boundary layer (from 35 to $65 \mathrm{~km}$ ), and equilibrating in some cases right up to the Moho. Such a scenario explains both the low velocity anomalies below the BPVF, and its geochemical and petrological evolution.

\section{Acknowledgments}

[51] This research was supported by the Earthscope Science Program at the National Science Foundation (EAR-07-45797 to TP and EAR 0745972 to DWF) and the Postdoctoral Fellowships in Earth, Environmental and Ocean Sciences from Lamont-Doherty Earth Observatory and Department of Earth and Environmental Sciences at Columbia University to EG. Sarah Hale carried out much of the original sample preparation and analysis of the Big Pine olivines and melt inclusions. We appreciate the technical support of Charles Mandeville at the AMNH during the electron probe data collection, Louis Bolge during the LA-ICP-MS data collection, and Jianhua Wang at CIW during SIMS data collection. Constructive reviews from Sally Gibson and an anonymous reviewer improved the original manuscript. Finally we want to acknowledge the editorial work of Joel Baker and the G-Cubed staff.

\section{References}

Artemieva, I. (2006), Global $1^{\circ} \times 1^{\circ}$ thermal model TC1 for the continental lithosphere: Implications for lithosphere secular evolution, Tectonophysics, 416(1-4), 245-277, doi:10.1016/ j.tecto.2005.11.022.

Aubaud, C., E. H. Hauri, and M. M. Hirschmann (2004), Hydrogen partition coefficients between nominally anhydrous minerals and basaltic melts, Geophys. Res. Lett., 31, L20611, doi:10.1029/2004GL021341.

Aubaud, C., A. C. Withers, M. M. Hirschmann, Y. Guan, L. A. Leshin, S. J. Mackwell, and D. R. Bell (2007), Intercalibration of FTIR and SIMS for hydrogen measurements in glasses and nominally anhydrous minerals, Am. Mineral., 92(5-6), 811-828, doi:10.2138/am.2007.2248.
Barrell, J. (1914), The strength of the Earth's crust, J. Geol., 22(7), 655-683, doi:10.1086/622181.

Beard, B., and A. F. Glazner (1995), Trace element and Sr and $\mathrm{Nd}$ isotopic composition of mantle xenoliths from the Big Pine volcanic field, California, J. Geophys. Res., 100(B3), 4169-4179, doi:10.1029/94JB02883.

Beattie, P. (1993), Olivine-melt and orthopyroxene-melt equilibria, Contrib. Mineral. Petrol., 115, 103-111.

Bennett, R. A., B. P. Wernicke, and J. L. Davis (1998), Continuous GPS measurements of contemporary deformation across the northern Basin and Range province, Geophys. Res. Lett., 25(4), 563-566, doi:10.1029/98GL00128.

Bercovici, D., and S.-I. Karato (2003), Whole-mantle convection and the transition-zone water filter, Nature, 425, 39-44, doi:10.1038/nature01918.

Blondes, M. S., P. W. Reiners, B. R. Edwards, and A. Biscontini (2007), Dating young basalt eruptions by (U-Th)/He on xenolithic zircons, Geology, 35(1), 17, doi:10.1130/G22956A.1.

Blondes, M. S., P. W. Reiners, M. N. Ducea, B. S. Singer, and J. Chesley (2008), Temporal-compositional trends over short and long time-scales in basalts of the Big Pine Volcanic Field, California, Earth Planet. Sci. Lett., 269(1-2), 140-154, doi:10.1016/j.epsl.2008.02.012.

Boyd, O. S., C. H. Jones, and A. F. Sheehan (2004), Foundering lithosphere imaged beneath the southern Sierra Nevada, California, USA, Science, 305, 660-662, doi:10.1126/ science. 1099181.

Canil, D. (2002), Vanadium in peridotites, mantle redox and tectonic environments: Archean to present, Earth Planet. Sci. Lett., 195, 75-90, doi:10.1016/S0012-821X(01)00582-9.

Chauvel, C., F. Lewin, M. Carpentier, N. T. Arndt, and J. C. Marini (2008), Role of recycled oceanic basalt and sediment in generating the Hf-Nd mantle array, Nat. Geosci., 1, 64-67.

Conrad, C. P., B. Wu, E. I. Smith, T. A. Bianco, and A. Tibbetts (2010), Shear-driven upwelling induced by lateral viscosity variations and asthenospheric shear: A mechanism for intraplate volcanism, Phys. Earth Planet. Inter., 178(3-4), 162-175, doi:10.1016/j.pepi.2009.10.001.

Conrad, C. P., T. A. Bianco, E. I. Smith, and P. Wessel (2011), Patterns of intraplate volcanism controlled by asthenospheric shear, Nat. Geosci., 4, 317-321, doi:10.1038/ngeo1111.

Cousens, B., J. Prytulak, C. Henry, A. Alcazar, and T. Brownrigg (2008), Geology, geochronology, and geochemistry of the Miocene-Pliocene Ancestral Cascades arc, northern Sierra Nevada, California and Nevada: The roles of the upper mantle, subducting slab, and the Sierra Nevada lithosphere, Geosphere, 4(5), 829, doi:10.1130/GES00166.1.

Crow, R., K. Karlstrom, Y. Asmerom, B. Schmandt, V. Polyak, and S. A. DuFrane (2011), Shrinking of the Colorado Plateau via lithospheric mantle erosion: Evidence from $\mathrm{Nd}$ and $\mathrm{Sr}$ isotopes and geochronology of Neogene basalts, Geology, 39(1), 27-30, doi:10.1130/G31611.1.

Danyushevsky, L. V., and P. Plechov (2011), Petrolog3: Integrated software for modeling crystallization processes, Geochem. Geophys. Geosyst., 12, Q07021, doi:10.1029/ 2011GC003516.

Danyushevsky, L. V., A. W. McNeill, and A. V. Sobolev (2002), Experimental and petrological studies of melt inclusions in phenocrysts from mantle-derived magmas: An overview of techniques, advantages and complications, Chem. Geol., 183, 5-24, doi:10.1016/S0009-2541(01)00369-2.

Dasgupta, R., M. M. Hirschmann, and N. D. Smith (2007), Partial melting experiments of peridotite $+\mathrm{CO}_{2}$ at $3 \mathrm{GPa}$ and genesis of alkalic ocean island basalts, J. Petrol., 48(11), 2093-2124, doi:10.1093/petrology/egm053. 
DePaolo, D. J., and E. E. Daley (2000), Neodymium isotopes in basalts of the southwest basin and range and lithospheric thinning during continental extension, Chem. Geol., 169, 157-185, doi:10.1016/S0009-2541(00)00261-8.

Dixon, J. E., and E. M. Stolper (1995), An experimental study of water and carbon dioxide solubilities in mid-ocean ridge basaltic liquids: Part II. Applications to degassing, J. Petrol., $36,1633-1646$.

Dixon, J. E., L. Leist, C. H. Langmuir, and J.-G. Schilling (2002), Recycled dehydrated lithosphere observed in plumeinfluenced mid-ocean-ridge basalt, Nature, 420, 385-389, doi:10.1038/nature01215.

Dixon, J., T. H. Dixon, D. R. Bell, and R. Malservisi (2004), Lateral variation in upper mantle viscosity: Role of water, Earth Planet. Sci. Lett., 222, 451-467.

Ducea, M. N., and J. Saleeby (1996), Buoyancy sources for a large, unrooted mountain range, the Sierra Nevada, California: Evidence from xenolith thermobarometry, J. Geophys. Res., 101(B4), 8229-8244, doi:10.1029/95JB03452.

Ducea, M. N., and J. B. Saleeby (1998), A case for delamination of the deep batholithic crust beneath the Sierra Nevada, California, Int. Geol. Rev., 40, 78-93, doi:10.1080/ 00206819809465199.

Dueker, K., H. Yuan, and B. Zurek (2001), Thick-structured Proterozoic lithosphere of the Rocky Mountain Region, GSA Today, 11, 4-9.

Elkins-Tanton, L. T., T. L. Grove, and J. Donnelly-Nolan (2001), Hot, shallow mantle melting under the Cascades volcanic arc, Geology, 29(7), 631-634.

Farmer, G. L., F. V. Perry, S. Semken, B. Crowe, D. Curtis, and D. J. DePaolo (1989), Isotopic evidence on the structure and origin of subcontinental lithospheric mantle in Southern Nevada, J. Geophys. Res., 94(B6), 7885-7898, doi:10.1029/ JB094iB06p07885.

Farmer, G. L., A. F. Glazner, and C. R. Manley (2002), Did lithospheric delamination trigger late Cenozoic potassic volcanism in the southern Sierra Nevada, California?, Geol. Soc. Am. Bull., 114(6), 754-768.

Fitton, J. G., D. James, and W. P. Leeman (1991), Basaltic magmatism associated with Late-Cenozoic extension in the Western United States: Compositional variations in space and time, J. Geophys. Res., 96(B8), 13,693-13,711, doi:10.1029/91JB00372.

Frassetto, A. M., G. Zandt, H. J. Gilbert, T. J. Owens, and C. H. Jones (2011), Structure of the Sierra Nevada from receiver functions and implications for lithospheric floundering, Geosphere, 7(4), 898-921.

Gribble, R. F., R. J. Stern, S. H. Bloomer, D. Stuben, T. O'Hearn, and S. Newman (1996), MORB mantle and subduction components interact to generate basalts in the southern Mariana Trough back-arc basin, Geochim. Cosmochim. Acta, 60(12), 2153-2166, doi:10.1016/0016-7037(96)00078-6.

Hammond, W. C., and E. D. Humphreys (2000), Upper mantle seismic wave velocity: Effects of realistic partial melt geometries, J. Geophys. Res., 105(B5), 10,975-10,986.

Hammond, W. C., and W. Thatcher (2004), Contemporary tectonic deformation of the Basin and Range province, western United States: 10 years of observation with the Global Positioning System, J. Geophys. Res., 109, B08403, doi:10.1029/ 2003JB002746.

Hauri, E. H. (1996), Major-element variability in the Hawaiian mantle plume, Nature, 382, 415-419, doi:10.1038/ $382415 \mathrm{a} 0$.

Hauri, E. H. (2002), SIMS analysis of volatiles in silicate glasses, 2: Isotopes and abundances in Hawaiian melt inclusions, Chem. Geol., 183, 115-141, doi:10.1016/S00092541(01)00374-6.

Hauri, E. H., G. A. Gaetani, and T. H. Green (2006), Partitioning of water during melting of the Earth's upper mantle at $\mathrm{H}_{2} \mathrm{O}$-undersaturated conditions, Earth Planet. Sci. Lett., 248, 715-734.

Herzberg, C. (2011), Identification of source lithology in the Hawaiian and Canary islands: Implications for origins, J. Petrol., 52(1), 113-146, doi:10.1093/petrology/egq075.

Herzberg, C., and P. D. Asimow (2008), Petrology of some oceanic island basalts: PRIMELT2.XLS software for primary magma calculation, Geochem. Geophys. Geosyst., 9, Q09001, doi:10.1029/2008GC002057.

Hirschmann, M. M. (2000), Mantle solidus: Experimental constraints and the effects of peridotite composition, Geochem. Geophys. Geosyst., 1(10), 1042, doi:10.1029/ 2000GC000070.

Hirschmann, M. M. (2010), Partial melt in the oceanic low velocity zone, Phys. Earth Planet. Inter., 179(1-2), 60-71, doi:10.1016/j.pepi.2009.12.003.

Hirschmann, M. M., and E. M. Stolper (1996), A possible role for garnet pyroxenite in the origin of the "garnet signature" in MORB, Contrib. Mineral. Petrol., 124, 185-208, doi:10.1007/s004100050184.

Hirschmann, M. M., T. Tenner, C. Aubaud, and A. C. Withers (2009), Dehydration melting of nominally anhydrous mantle: The primacy of partitioning, Phys. Earth Planet. Inter., 176(1-2), 54-68, doi:10.1016/j.pepi.2009.04.001.

Hirth, G., and D. L. Kohlstedt (1996), Water in the oceanic upper mantle: Implications for rheology, melt extraction and the evolution of the lithosphere, Earth Planet. Sci. Lett., 144(1-2), 93-108, doi:10.1016/0012- 821X(96)00154-9.

Hofmann, A. W., and M. Feigenson (1983), Case studies on the origin of basalts: I. Theory and reassessment of Grenada basalts, Contrib. Mineral. Petrol., 84, 382-389, doi:10.1007/ BF01160289.

Hofmann, A. W., and W. M. White (1982), Mantle plumes from ancient oceanic crust, Earth Planet. Sci. Lett., 57, 421-436, doi:10.1016/0012-821X(82)90161-3.

Holtzman, B. K., and J. M. Kendall (2010), Organized melt, seismic anisotropy, and plate boundary lubrication, Geochem. Geophys. Geosyst., 11, Q0AB06, doi:10.1029/ $2010 \mathrm{GC} 003296$.

Humphreys, E., E. Hessler, K. G. Dueker, G. L. Farmer, E. A. Erslev, and T. A. Atwater (2003), How Laramide-age hydration of North American lithosphere by the Farallon slab controlled subsequent activity in the Western United States, Int. Geol. Rev, 45, 575-595.

Jackson, I., U. H. Faul, J. D. Fitz Gerald, and B. H. Tan (2004), Shear wave attenuation and dispersion in melt-bearing olivine polycrystals: 1 . Specimen fabrication and mechanical testing, J. Geophys. Res., 109, B06201, doi:10.1029/ 2003JB002406.

Jackson, M. G., and R. Dasgupta (2008), Compositions of HIMU, EM1, and EM2 from global trends between radiogenic isotopes and major elements in ocean island basalts, Earth Planet. Sci. Lett., 276(1-2), 175-186, doi:10.1016/ j.eps1.2008.09.023

Johnson, E. R., P. J. Wallace, H. Delgado Granados, V. C. Manea, A. J. R. Kent, I. N. Bindeman, and C. S. Donegan (2009), Subduction-related volatile recycling and magma generation beneath Central Mexico: Insights from melt inclusions, oxygen isotopes and geodynamic models, J. Petrol., 50(9), 1729-1764, doi:10.1093/petrology/egp051. 
Jones, C. H., and R. A. Phinney (1998), Seismic structure of the lithosphere from teleseismic converted arrivals observed at small arrays in the southern Sierra Nevada and vicinity, California, J. Geophys. Res., 103(B5), 10,065-10,090.

Jones, C. H., H. Kanamori, and S. W. Roecker (1994), Missing roots and mantle "drips": Regional Pn and teleseismic arrival times in the southern Sierra Nevada and vicinity, California, J. Geophys. Res., 99(B3), 4567-4601.

Jones, C. H., G. L. Farmer, and J. Unruh (2004), Tectonics of Pliocene removal of lithosphere of the Sierra Nevada, California, Geol. Soc. Am. Bull., 116(11), 1408, doi:10.1130/ B25397.1.

Jordan, T. H. (1978), Composition and development of the continental tectosphere, Nature, 274, 544-548.

Jugo, P. J., M. Wilke, and R. E. Botcharnikov (2010), Sulfur K-edge XANES analysis of natural and synthetic basaltic glasses: Implications for $\mathrm{S}$ speciation and $\mathrm{S}$ content as function of oxygen fugacity, Geochim. Cosmochim. Acta, 74(20), 5926-5938.

Karato, S. (2003), Mapping water content in the upper mantle, in Inside the Subduction Factory, Geophys. Monogr. Ser., vol. 138, edited by J. Eiler, pp. 135-152, AGU, Washington, D. C., doi:10.1029/138GM08.

Karato, S., and H. Jung (1998), Water, partial melting and the origin of the seismic low velocity and high attenuation zone in the upper mantle, Earth Planet. Sci. Lett., 157, 193-207.

Katz, R. F., M. Spiegelman, and C. H. Langmuir (2003), A new parameterization of hydrous mantle melting, Geochem. Geophys. Geosyst., 4(9), 1073, doi:10.1029/2002GC000433.

Kelemen, P. B., G. M. Yogodzinski, and D. W. Scholl (2003), Along-strike variation in the Aleutian island arc: Genesis of high $\mathrm{Mg \#}$ andesite and implications for continental crust, in Inside the Subduction Factory, Geophys. Monogr. Ser., vol. 138, edited by J. Eiler, pp. 223-273, AGU, Washington, D. C.

Kelley, K. A., and E. Cottrell (2009), Water and the oxidation state of subduction zone magmas, Science, 325(5940), 605-607, doi:10.1126/science.1174156.

Kelley, K. A., and E. Cottrell (2012), The influence of magmatic differentiation on the oxidation state of $\mathrm{Fe}$ in a basaltic arc magma, Earth Planet. Sci. Lett., 329-330, 109-121.

Kelley, K. A., T. Plank, T. L. Grove, E. M. Stolper, S. Newman, and E. Hauri (2006), Mantle melting as a function of water content beneath back-arc basins, J. Geophys. Res., 111, B09208, doi:10.1029/2005JB003732.

Kelley, K. A., T. Plank, S. Newman, E. M. Stolper, T. L. Grove, S. Parman, and E. H. Hauri (2010), Mantle melting as a function of water content beneath the Mariana Arc, J. Petrol., 51(8), 1711-1738, doi:10.1093/petrology/egq036.

Kirby, E., S. Anandakrishnan, F. Phillips, and S. Marrero (2008), Late Pleistocene slip rate along the Owens Valley fault, eastern California, Geophys. Res. Lett., 35, L01304, doi:10.1029/2007GL031970.

Kogiso, T., M. M. Hirschmann, and M. Petermann (2004), High-pressure partial melting of mafic lithologies in the mantle, J. Petrol., 45(12), 2407-2422, doi:10.1093/petrology/ egh057.

Koleszar, A. M., A. E. Saal, E. H. Hauri, A. N. Nagle, Y. Liang, and M. D. Kurz (2009), The volatile contents of the Galapagos plume; evidence for $\mathrm{H}_{2} \mathrm{O}$ and $\mathrm{F}$ open system behavior in melt inclusions, Earth Planet. Sci. Lett., 287(3-4), 442-452, doi:10.1016/j.epsl.2009.08.029.

Kress, V. C., and I. S. E. Carmichael (1991), The compressibility of silicate liquids containing $\mathrm{Fe}_{2} \mathrm{O}_{3}$ and the effect of composition: Temperature: oxygen fugacity and pressure on their redox states, Contrib. Mineral. Petrol., 108, 82-92.

Langmuir, C. H., A. Bézos, S. Escrig, and S. W. Parman (2006), Chemical systematics and hydrous melting of the mantle in back-arc basins, in Back-Arc Spreading Systems: Geological, Biological, Chemical, and Physical Interactions, Geophys. Monogr. Ser., vol. 166, edited by D. M. Christie et al., pp. 87-146, AGU, Washington, D. C., doi:10.1029/ 166GM07.

Lee, C.-T. A. (2005), Trace element evidence for hydrous metasomatism at the base of the North American lithosphere and possible association with Laramide low-angle subduction, J. Geol., 113, 673-685, doi:10.1086/449327.

Lee, C.-T. A. (2012), Physics and chemistry of deep continental crust recycling, in Treatise in Geochemistry, Elsevier, Amsterdam, in press.

Lee, C.-T. A., Q. Yin, R. L. Rudnick, J. Chesley, and S. B. Jacobsen (2000), Osmium isotopic evidence for Mesozoic removal of lithospheric mantle beneath the Sierra Nevada, California, Science, 289, 1912-1916, doi:10.1126/science. 289.5486.1912.

Lee, C.-T., R. L. Rudnick, and G. H. Brimhall Jr. (2001), Deep lithospheric dynamics beneath the Sierra Nevada during the Mesozoic and Cenozoic as inferred from xenolith petrology, Geochem. Geophys. Geosyst., 2(12), 1053, doi:10.1029/ 2001GC000152.

Lee, C.-T. A., P. Luffi, T. Plank, H. Dalton, and W. P. Leeman (2009), Constraints on the depths and temperatures of basaltic magma generation on Earth and other terrestrial planets using new thermobarometers for mafic magmas, Earth Planet. Sci. Lett., 279(1-2), 20-33, doi:10.1016/j.epsl.2008. 12.020 .

Leeman, W. P., and D. L. Harry (1993), A binary source model for extension-related magmatism in the Great Basin, Western North America, Science, 262, 1550-1554, doi:10.1126/ science.262.5139.1550.

Le Roux, V., C. T. A. Lee, and S. J. Turner (2010), Zn/Fe systematics in mafic and ultramafic systems: Implications for detecting major element heterogeneities in the Earth's mantle, Geochim. Cosmochim. Acta, 74(9), 2779-2796.

Levander, A., B. Schmandt, M. S. Miller, K. Liu, K. E. Karlstrom, R. S. Crow, C. T. Lee, and E. D. Humphreys (2011), Continuing Colorado plateau uplift by delamination-style convective lithospheric downwelling, Nature, 472(7344), 461-465, doi:10.1038/nature10001.

Li, Z.-X. A., C.-T. A. Lee, A. H. Peslier, A. Lenardic, and S. J. Mackwell (2008), Water contents in mantle xenoliths from the Colorado Plateau and vicinity: Implications for the mantle rheology and hydration-induced thinning of continental lithosphere, J. Geophys. Res., 113, B09210, doi:10.1029/ $2007 \mathrm{JB} 005540$.

Lloyd, A. S., T. Plank, P. Ruprecht, E. H. Hauri, and W. I. Rose (2010), Volatile loss from melt inclusions in clasts of differing sizes, Abstract V24C-04 presented at 2010 Fall Meeting, AGU, San Francisco, Calif., 13-17 Dec.

Lowry, A. R., N. M. Ribe, and R. B. Smith (2000), Dynamic elevation of the Cordillera, western United States, J. Geophys. Res., 105(B10), 23,371-23,390, doi:10.1029/2000JB900182.

Mallmann, G., and H. S. C. O’Neill (2009), The crystal/melt partitioning of $\mathrm{V}$ during mantle melting as a function of oxygen fugacity compared with some other elements (Al, P, Ca, Sc, Ti, Cr, Fe, Ga, Y, Zr and Nb), J. Petrol., 50(9), 1765-1794, doi:10.1093/petrology/egp053.

Manley, C. R., A. F. Glazner, and G. L. Farmer (2000), Timing of volcanism in the Sierra Nevada of California: Evidence for 
Pliocene delamination of the batholithic root?, Geology, 28(9), 811-814, doi:10.1130/0091-7613(2000)28<811:TOVITS > 2.0.CO;2.

McDonough, W. F., and S.-S. Sun (1995), The composition of the Earth, Chem. Geol., 120, 223-253, doi:10.1016/00092541(94)00140-4.

McKenzie, D., and M. J. Bickle (1988), The volume and composition of melt generated by extension of the lithosphere, J. Petrol., 29(3), 625-679.

McQuarrie, N., and M. Oskin (2010), Palinspastic restoration of NAVDat and implications for the origin of magmatism in southwestern North America, J. Geophys. Res., 115, B10401, doi:10.1029/2009JB006435.

Mordick, B. E., and A. F. Glazner (2006), Clinopyroxene thermobarometry of basalts from the Coso and Big Pine volcanic fields, Contrib. Mineral. Petrol., 152, 111-124.

Moucha, R., A. M. Forte, D. B. Rowley, J. X. Mitrovica, N. A. Simmons, and S. P. Grand (2008), Mantle convection and the recent evolution of the Colorado Plateau and the Rio Grande Rift valley, Geology, 36(6), 439-442, doi:10.1130/ G24577A.1.

Newman, S., and J. B. Lowenstern (2002), VolatileCalc: A silicate melt $-\mathrm{H}_{2} \mathrm{O}-\mathrm{CO}_{2}$ solution model written in Visual Basic for Excel, Comput. Geosci., 28, 597-604, doi:10.1016/ S0098-3004(01)00081-4.

Ohtani, E. (2005), Water in the mantle, Elements, 1, 25-30, doi:10.2113/gselements.1.1.25.

Ormerod, D. S., C. J. Hawkesworth, N. W. Rogers, W. P. Leeman, and M. Menzies (1988), Tectonic and magmatic transitions in the Western Great Basin, USA, Nature, 333, 349-353, doi:10.1038/333349a0.

Ormerod, D. S., N. W. Rogers, and C. J. Hawkesworth (1991), Melting in the lithospheric mantle: Inverse modelling of alkali-olivine basalts from the Big Pine Vocanic Field, California, Contrib. Mineral. Petrol., 108, 305-317, doi:10.1007/BF00285939.

Perry, F. V., S. W. Baldridge, and D. J. DePaolo (1987), Role of asthenosphere and lithosphere in the genesis of Late Cenozoic basaltic rocks from the Rio Grande rift and adjacent regions of the southwestern United States, J. Geophys. Res., 92(B9), 9193-9213.

Phillips, F. M., and L. Majkowski (2011), The role of low-angle normal faulting in active tectonics of the northern Owens Valley, California, Lithosphere, 3(1), 22-36, doi:10.1130/L73.1.

Pikser, J. E., D. W. Forsyth, and G. Hirth (2012), Along-strike translation of a fossil slab, Earth Planet. Sci. Lett., 331-332, 315-321, doi:10.1016/j.epsl.2012.03.027.

Plank, T., L. B. Cooper, and C. E. Manning (2009), Emerging geothermometers for estimating slab surface temperatures, Nat. Geosci., 2, 611-615, doi:10.1038/ngeo614.

Portnyagin, M., R. Almeev, S. Matveev, and F. Holtz (2008), Experimental evidence for rapid water exchange between melt inclusions in olivine and host magma, Earth Planet. Sci. Lett., 272(3-4), 541-552, doi:10.1016/j.epsl.2008.05.020.

Rau, C. J., and D. W. Forsyth (2011), Melt in the mantle beneath the amagmatic zone, southern Nevada, Geology, 39(10), 975-978, doi:10.1130/G32179.1.

Ritzwoller, M. H., N. M. Shapiro, and S. Zhong (2004), Cooling history of the Pacific lithosphere, Earth Planet. Sci. Lett., 226, 69-84.

Ruscitto, D. M., P. J. Wallace, E. R. Johnson, A. J. R. Kent, and I. N. Bindeman (2010), Volatile contents of mafic magmas from cinder cones in the Central Oregon High Cascades: Implications for magma formation and mantle conditions in a hot arc, Earth Planet. Sci. Lett., 298(1-2), 153-161, doi:10.1016/j.eps1.2010.07.037.

Ruscitto, D., P. J. Wallace, L. Cooper, and T. Plank (2012) Global variations in $\mathrm{H}_{2} \mathrm{O}$ /Ce II: Relationships to arc magma geochemistry and volatile fluxes, Geochem. Geophys. Geosyst., 13, Q03025, doi:10.1029/2011GC003887.

Rychert, C. A., and P. M. Shearer (2009), A global view of the lithosphere-asthenosphere boundary, Science, 324(5926), 495-498.

Rychert, C. A., P. M. Shearer, and K. M. Fischer (2010), Scattered wave imaging of the lithosphere-asthenosphere boundary, Lithos, 120(1-2), 173-185, doi:10.1016/j.lithos. 2009.12.006

Saal, A., E. Hauri, C. H. Langmuir, and M. R. Perfit (2002), Vapour undersaturation in primitive mid-ocean-ridge basalt and the volatile content of Earth's upper mantle, Nature, 419, 451-455, doi:10.1038/nature01073.

Sadofsky, S. J., M. Portnyagin, K. Hoernle, and P. Bogaard (2008), Subduction cycling of volatiles and trace elements through the Central American volcanic arc: Evidence from melt inclusions, Contrib. Mineral. Petrol., 155(4), 433-456, doi:10.1007/s00410-007-0251-3.

Salters, V. J. M., and A. Stracke (2004), Composition of the depleted mantle, Geochem. Geophys. Geosyst., 5, Q05B07, doi:10.1029/2003GC000597.

Savage, B., C. Ji, and D. V. Helmberger (2003), Velocity variations in the uppermost mantle beneath the southern Sierra Nevada and Walker Lane, J. Geophys. Res., 108(B7), 2325, doi:10.1029/2001JB001393.

Savage, M. K., and A. F. Sheehan (2000), Seismic anisotropy and mantle flow from the Great Basin to the Great Plains, western United States, J. Geophys. Res., 105(B6), 13,715-13,734.

Schiano, P., J. M. Eiler, I. D. Hutcheon, and E. M. Stolper (2000), Primitive $\mathrm{CaO}$-rich, silica-undersaturated melts in island arcs: Evidence for the involvement of clinopyroxenerich lithologies in the petrogenesis of arc magmas, Geochem. Geophys. Geosyst., 1(5), 1018, doi:10.1029/1999GC000032.

Schmandt, B., and E. Humphreys (2010), Complex subduction and small-scale convection revealed by body-wave tomography of the western United States upper mantle, Earth Planet. Sci. Lett., 297, 435-445, doi:10.1016/j.epsl.2010.06.047.

Schmandt, B., and E. Humphreys (2011), Seismically imaged relict slab from the 55 Ma Siletzia accretion to the northwest United States, Geology, 39(2), 175-178, doi:10.1130/ G31558.1.

Schulze, D. J. (1989), Constraints on the abundance of eclogite in the upper mantle, J. Geophys. Res., 94(B4), 4205-4212, doi:10.1029/JB094iB04p04205.

Simons, K., J. Dixon, J.-G. Schilling, R. Kingsley, and R. Poreda (2002), Volatiles in basaltic glasses from the Easter-Salas y Gomez Seamount Chain and Easter Microplate: Implications for geochemical cycling of volatile elements, Geochem. Geophys. Geosyst., 3(7), 1039, doi:10.1029/2001GC000173.

Sobolev, A. V., A. W. Hofmann, S. V. Sobolez, and I. K. Nikogosian (2005), An olivine-free mantle source of Hawaiian shield basalts, Nature, 434, 590-597, doi:10.1038/ nature 03411.

Sobolev, A. V., et al. (2007), The amount of recycled crust in sources of mantle-derived melts, Science, 316(5823), 412-417, doi:10.1126/science. 1138113.

Stockli, D. F., T. A. Dumitru, M. O. McWilliams, and K. A. Farley (2003), Cenozoic tectonic evolution of the White Mountains, California and Nevada, Geol. Soc. Am. Bull., 
115(7), 788-816, doi:10.1130/0016-7606(2003)115<0788: CTEOTW $>2.0 . \mathrm{CO} ; 2$.

Stolper, E., S. Sherman, G. Michael, M. Baker, and C. Seaman (2004), Glass in the submarine section of the HSDP2 drill core, Hilo, Hawaii, Geochem. Geophys. Geosyst., 5, Q07G15, doi:10.1029/2003GC000553.

Tenner, T. J., M. M. Hirschmann, A. C. Withers, and R. L. Hervig (2009), Hydrogen partitioning between nominally anhydrous upper mantle minerals and melt between 3 and $5 \mathrm{GPa}$ and applications to hydrous peridotite partial melting, Chem. Geol., 262(1-2), 42-56, doi:10.1016/j.chemgeo.2008. 12.006 .

Trønnes, R. G. (2002), Stability range and decomposition of potassic richterite and phlogopite end members at 5-15 GPa, Mineral. Petrol., 74, 129-148, doi:10.1007/s007100200001.

Wallace, P. J., and A. T. Anderson Jr. (1998), Effects of eruption and lava drainback on the $\mathrm{H}_{2} \mathrm{O}$ contents of basaltic magmas at Kilauea Volcano, Bull. Volcanol., 59, 327-344, doi:10.1007/s004450050195.

Wang, K., T. Plank, J. D. Walker, and E. I. Smith (2002), A mantle melting profile across the Basin and Range, SW USA, J. Geophys. Res., 107(B1), 2017, doi:10.1029/ 2001JB000209.

Wernicke, B. P., R. L. Christiansen, P. C. England, and L. J. Sonder (1987), Tectonomagmatic evolution of Cenozoic extension in the North American Cordillera, in Continental Extensional Tectonics, edited by M. P. Coward, J. F. Dewey, and P. L. Hancock, Geol. Soc. Spec. Publ., 28, 203-221.
Wernicke, B., et al. (1996), Origin of high mountains in the continents: The southern Sierra Nevada, Science, 271, 190-193, doi:10.1126/science.271.5246.190.

West, J. D., M. J. Fouch, J. B. Roth, and L. T. Elkins-Tanton (2009), Vertical mantle flow associated with a lithospheric drip beneath the Great Basin, Nat. Geosci., 2(6), 439-444, doi:10.1038/ngeo526.

Workman, R. K., and S. R. Hart (2005), Major and trace element composition of the depleted MORB mantle (DMM), Earth Planet. Sci. Lett., 231(1-2), 53-72, doi:10.1016/ j.epsl.2004.12.005.

Yang, Y., and D. W. Forsyth (2006), Rayleigh wave phase velocities, small-scale convection, and azimuthal anisotropy beneath southern California, J. Geophys. Res., 111, B07306, doi:10.1029/2005JB004180.

Zandt, G. (2003), The southern Sierra Nevada drip and the mantle wind direction beneath the southwestern United States, Int. Geol. Rev., 45, 213-224, doi:10.2747/0020-6814.45.3.213.

Zandt, G., H. J. Gilbert, T. J. Owens, M. N. Ducea, J. Saleeby, and C. H. Jones (2004), Active foundering of a continental arc root beneath the southern Sierra Nevada in California, Nature, 431, 41-46, doi:10.1038/nature02847.

Zimmer, M. M., T. Plank, E. H. Hauri, G. M. Yogodzinski, P. Stelling, J. Larsen, B. Singer, B. Jicha, C. Mandeville, and C. J. Nye (2010), The role of water in generating the calc-alkaline trend: New volatile data for aleutian magmas and a new tholeiitic index, J. Petrol., 51(12), 2411-2444, doi:10.1093/petrology/egq062. 